\title{
Trabalhadores e cidadania Experiência do mundo público na história do Brasil moderno
}

\author{
Marla Cella Paoli
}

\section{Introduçāo}

A questâo de se entender e propor os caminhos para a democracia no Brasil - questāo sempre atormentada pelo desencontro entre as reivindicaçōes da ação coletiva e o realismo em política, tendo como pano de fundo os amargos pesadelos das ditaduras, dos populismos, dos privilégios, das impunidades, das desigualdades - parece ter mudado de qualidade nestes anos 80 . Trata-se de uma mudança em sua formulação: interroga-se menos a arte de governar e suas condiçōes institucionais do que a constituição de uma sociabilidade política democrática na experiência histórica, coletiva, da sociedade brasileira. Em uma palavra, a interrogação parece se deslocar, cada vez mais, para os problemas e as dificuldades da constituição de um domínio público nesta sociedade, entendido também cada vez mais como condição essencial e fundante de suas poss1bilidades democráticas.

Este deslocamento da interrogaçāo sobre as possibilidades da democracia não significa que se deixe de lado o entendimento do funcionamento do poder do Estado. Mas, sim, significa interrogá-lo a partir das formas de cultura e dos universos simbólicos que perpassam a sociedade: quais os fundamentos do exercício de seu direito e das formas de distribuição (formais e informais) da justiça; qual a encenação de si mesma e de sua população a partir da qual se avalia suas possibilidades e impossibilidades; qual a forma como nela se praticam as concepçōes sobre a legitimidade da ordem social e dos conflitos. Sobretudo, significa querer conhecer as práticas que envolvem o reconhecimento das diferenças entre grupos e classes sociais como experiência histórica de uma situaçāo comum: de que universo se distinguem os muitos outros na trama do social, como se desdobram os mundos da desigualdade e da equivalência, como decifrar politicamente a vida coletiva em uma sociedade tão radicalmente desigual? ${ }^{\text {. }}$

Desse ponto de vista, a interrogação atual sobre a democracia $e$, quase inevitavelmente, uma interrogação histórica. Pois se trata de saber, não de uma idéia, mas de uma experiência, vivida no tempo, de instituição de uma sociedade; experiência esta que nos chega cheia de possíveis, implicados (como algo de novo) nos acontecimentos e práticas coletivas das duas últimas décadas. Neste sentido, a interrogação histórica sobre esta sociedade é simultaneamente antecipação e rememoração no tempo presente. Antecipação de uma possibili-

1 A noção de espaço público e de democracia aqui utilizada se inspira em Hannah Arendt, As origens do totalitarismo. Documentário, Rio de Janeiro, 1979; e na discussảo que Lefort faz sobre o pensamento de Tocqueville: Claude Lefort, Essais sur le politique Paris, Editions du Seuil, 1986. 
dade democrática em uma sociedade que, após um século de republicanismo e industrialização, entra no mundo contemporâneo com uma modernidade incompleta; como analisa Chauí (1986), uma sociedade onde há uma indistinção entre o público e o privado, uma incapacidade para fazer valer a igualdade jurídica formal, uma forte hierarquia de privilégios e lugares sociais, uma complexa e variada estrutura de preconceitos, uma mescla indistinguível entre o arbítrio e a transgressão, uma violência espantosa para impedir a reinvenção coletiva e, talvez o que mais impressiona, uma conexão aparentemente muito pouco necessária entre as capacidades coletivas de julgar, querer e agir nos momentos fortes de expressão política. Ao mesmo tempo, rememorar uma sociedade autoritária e excludente quando se tornam visiveis as açōes e representaçōes inovadoras dos movimentos sociais, que redefinem as referências anteriormente existentes para as regras reais do jogo político e apontam para uma nova elaboraçāo da legitimidade porque representam uma nova experiência de mundo público. Antecipar e rememorar a experiência de constituição da moderna sociedade brasileira é, então, não poder ancorar a interrogação democrática em qualquer lógica modelar de relações e determinaçōes unívocas a respeito do caráter desta experiência, nem em grandes inventários de elementos sociais classificáveis e rearranjados para explicar sua possibilidade e nem mesmo em "adaptações" históricas de outros "casos" de democratização. Não se trata de construir uma matriz ou modelo de transição histórica, mas de pensar a dinâmica política de uma sociedade cuja experiência, embora comparável, é singular - em sua historicidade, na construção de seus referenciais simbólicos e no seu tempo próprio de enunciaçāo da questão democrática.

Por onde veio esta nova sensibilidade à questão democrática? Parece claro que a interrogação sobre a difícil constituição de um espaço público democrático neste país tem fortes raízes nos acontecimentos das duas últimas décadas, sobretudo quando novos personagens entraram na cena social e política do País (SÁDER, 1988) ${ }^{2}$, na forma de movimentos sociais plurais e autônomos, numa sociedade que então buscava sair da ditadura militar. $O$ aparecimento destes movimentos na década de $70 \mathrm{e}$, desde então, sua continuada presença (às vezes triunfante, às vezes apagada, às vezes derrotada) nessa cena estão profundamente correlacionados ao fato de hoje podermos definir as questōes relativas à constituição de um espaço público democrático como centrais à compreensão da dinâmica política do social. $\mathrm{E}$ isto em vários sentidos. Primeiro, porque como mostra a literatura a respeito - eles se afirmaram quase à revelia da teoria sociológica consagrada e nem por isso puderam servir de exemplo para mais um desvio do correto rumo histórico da sociedade. Sāo movimentos múltiplos que emergem de vários pontos do espaço social e que dificilmente se universalizam, do modo esperado, em relação ao poder instituído. Não têm uma base classista necessária ou homogênea nem se constituem dentro de formas organizativas e discursivas já conhecidas; quando estas emergem em alguns destes movimentos,

\footnotetext{
2 Ver, também, Vera Silva Telles, A experiência do autoritarismo e as práticas instintintes. São Paulo, USP, 1984. Dissertação de Mestrado. Paul Singer e Vinícius C. Brandr, São Paulo, o povo em movimento. Vozes, 1980; Ruth Cardoso, Movimentos sociais, balanço crítico. In: Sorj e Almeida, Sociedade e poltica no Brasil pós-64. São Paulo, Brasiliense, 1983: Laís Abramo, O resgate da dignidade. São Paulo, USP, 1986. Dissertação de Mestrado. Silvio Caccia-Bava, Práticas cotidianas e movimentos sociais. São Paulo, USP, 1983. Dissertacão de Mestrado. Nabil Bonduki, Construindo rerritorios da utopia. São Paulo, USP, 1987. Tese de Mestrado. Irlys Barreira, Refazendo a política. São Paulo, USP, 1987. Tese de Doutorado. Maria Celia Paoli e Eder Sáder, Sobre classes populares no pensamento sociológico brasileiro. In: Cardoso, R., org. A aventura antropologica. Sảo Paulo, Paz e Terra, 1986.
} 
são tratadas como opçōes políticas debatidas e não como inevitabilidades históricas. Segundo, porque estes movimentos mantêm viva a sua diferença interna, enfatizando desigualmente as dimensões reivindicativas; convivem diversamente no espaço social movimentos por direitos sociais propriamente ditos, por direitos culturais, por direitos humanos, por direitos econômicos e sindicais e por direitos de expressão. Cada ênfase destas encontra forma na ação que organiza cada identidade coletiva e seu campo de atuação. Terceiro, e o mais fundamental que aqui interessa, porque - embora os caminhos de seu encontro sejam difíceis de serem achados na medida em que é recusada sua universalização politicamente hierárquica e discursivamente homogênea - parece claro que os movimentos sociais em seu conjunto já conseguiram gerar um horizonte cultural para a política, cuja novidade é o reestabelecimento da inventividade das noçōes de "direitos" e de "cidadania" como chaves de acesso à dimensão política da vida social. Quarto, porque - como conseqüência disso tudo - foram os movimentos sociais que deram corpo e concretude ao modo como, no Brasil de hoje, a esfera da política instituída se distancia da esfera da ação social, algo que às vezes é visto como conhecido e já previsto pela teoria. A busca ativa da política a partir da vivência do social adquire seu sentido histórico, no Brasil, porque é feita em uma sociedade cuja experiência ampliada de participação civil inexiste e cuja noção de negociação política é extremamente excludente. Daí o impacto de sua presença nesta sociedade que, talvez pela primeira vez, está concebendo a produção de uma vida pública a partir de um mundo comum feito de experiências distintas de conflito e de acordo - ousando, portanto, conferir-lhes legitimidade e reconhecendo-lhes o direito a inscreverem-se (como reivindicação e ação organizada) na política. Isto pode ser visto tanto nas falas dos diferentes poderes sociais, agora quase sempre dispostos a negociações abertas, quanto nas premissas explíticas ou implícitas de teses acadêmicas ou dos textos que formam a opinião pública, dispostos a aceitar uma horizontalidade de valores da cultura e da política antes impensável diante dos critérios normativos do que é correto ou bom neste campo. Para não falar de sua inscrição no texto máximo de ordenaçāo política do País, a Constituição que, ora, tem vigência ${ }^{3}$.

Não é de espantar, portanto, que as ciências humanas acolham a noção de cidadania e de direitos como uma das idéias fundantes sobre o Brasil de hoje. Uma noção claramente reformulada se pensarmos em seu significado político original clássico, como o direito à representaçāo pelo voto e às garantias e liberdades civis, tendo como unidade o indivíduo. Ao que tudo indica, os cientistas sociais que hoje se debruçam sobre a questão da cidadania tentam construí-la em outro campo de referência. Este parece ser feito (entre outras coisas) das seguintes questões: primeiro, se é possível concebê-la a partir de um suporte coletivo não-corporativo, ou seja, algo como uma "cidadania coletiva" fundada em práticas que se transformam constantemente e que lutam, de modos diversos, pelo reconhecimento público de suas demandas. A rica e renovada produção recente dos pensadores jurídicos que, nesta década, buscam refletir

3

Sobre a incorporação de reivindicaçóes populares na Constituição de 1988 e sobre o processo na constituinte, ver Paulo Sergio Moçouçah, Movimentos sociais, instituição e democracia: a participaçāo popular na Constituinte, 1988 (mimeografado); João G. L. Coelho, Duelo entre o novo e o antigo, Humanidades, 19,1988; Carlos Michiles et alii, Cidadão constituinte: a saga das emendas populares. São Paulo, Paz e Terra, 1989.
..: por que 0 engendramento historico do espaço polftico moderno no Brasil excluiu a dimensão pablica entendida nos termos acima da sua sociabilidade? 
sobre as relaçōes entre direito e justiça, parece caminhar nesta direção 4 . Em segundo lugar, esta noçảo recupera o sentido e a importância da vida social comum e quotidiana como base para açāo e para a concepção de direitos diversos, mas equivalentes, de cidadania. Em terceiro lugar, a idéia da sociedade democrática que daí desponta parece ser aquela na qual o espaço e o tempo políticos abrem-se para uma articulaçāo e interpenetração destes diversos direitos em seus conflitos e consensos, de modo que a sociedade possa conhecer um movimento de ampliação de direitos e de sua regulamentaçẩo que tenha por base não a lealdáde individual ao poder, mas a efetiva participaçăo comum em sua produção e instituição. Nestes termos, a dimensão utópica desta noção de cidadania é constitutiva de seu movimento de percepção histớrica e de construçāo categorial. Ela encontra, no entanto, seu rigor no plano histórico, ao buscar nele os parâmetros do seu sentido. Este parece nutrir-se das ambigüidades entre o possf́vel e o desejável, postos no movimento do real; isto abre a formulação para pensar sujeitos atuantes que, longe de serem figuras teóricas ou fenômenos empíricos isolados, possam ter presença dinâmica diante de um poder cujo dilema é o de encontrar formas legftimas de democratização para além de princípios cristalizados ou consideraçōes técnicas 5 .

Assim, o ponto crucial desta reformulação da noção de cidadania que vem da nova sensibilidade intelectual ao fazer-se histórico de uma sociedade pode ser sintetizada na questáo: de que modo o "direito a conquistar o próprio direito à cidadania" (CHAUI, 1986) ou, em outros termos, o reconhecimento público do "direito a ter direitos" (ARENDT, 1979 e LEFORT, 1986) pode se processar e se exteriorizar no domínio público de modo a conferir legitimidade e credibilidade as instituiçōes políticas? Quando os cientistas sociais anotam, nos movimentos sociais contemporâneos, as reivindicaçōes de expressão e visibilidade, de exteriorização dos conflitos, de autónomia e de busca de justiça social'; quando percebem o desejo de acesso aos mecanismos de informaçāo, formação e decisão; e, sobretudo, quando vêem a demanda a um reconhecimento de sociabilidade e cultura que impeça sua desorganizaçāo pelo poder instituído, eles abrem-se para uma nova avaliaçāo da dimensāo democrática do social. Nestes termos, a questão se referencia em um campo de ação e representação onde a diversidade possa ganhar forma política. A cidadania assim pensada será a tentativa de desenvolver este mundo possível de representaçäo de interesses plurais.

Este texto procura explorar as vias abertas sobre a questāo da cidadania e da democracia na sociedade brasileira, através de uma questāo levantada pelo debate atual: por que o engendramento histórico do espaço político moderno no Brasil excluiu a dimensão pública - entendida nos termos acima - da sua sociabilidade? Ou, em outros termos: como foi possivel que os temas e as lutas em torno da desigualdade, da injustiça, da participação popular, da legitimidade e da representação tenham estado no próprio âmago da história moderna do País

4 Cf. Sousa Jr., J. G., org. O direito achado na nua 1. ed., Brastlia, UnB, 1987 e Faria, J. E., org. Direito e Justiça. Såo Paulo, Atica, 1989.

${ }^{5}$ Sobre a prática cientffica das ciencias sociais hoje, cf. Boaventura de Sousa Santos, "O social e o polftico na transiçẵo pós-moderna" em Revista de Comunicação e Lunguagens (6-7), 1988.

6 Cf. Vera da Silva Telles, Espaços públicos, direitos e cidadania, 1989 (mimeografado). Texto apresentado no V Congresso Estadual dos Sociologos do Estado de Săo Paulo, na mesa-redonda: “A cidadania hoje: igualdade e diferença na sociedade brasileira". 
e, mesmo assim, a esfera pública enquanto espaço democrático de reconhecimento, representação e negociação tenha sido tão difícil de se tematizar e visualizar?

\section{Trabalhadores e Pobres na República: privatização e ilegalidade}

Decifrar uma sociedade que evitou colocar a questão da cidadania e da democratização diante da heterogeneidade de sua instituição social moderna implica em perceber, creio, o lugar que abriu para a representação de suas classes populares: figuras cujos traços e predicados são atribuídos a partir de critérios que discemem a validade e o escopo da dimensão pública que uma sociedade é capaz de elaborar. Quais eram estes criterios que presidiram a formação de uma sociedade de classes, ou seja, no interior de quais regras simbólicas se constituíram dominantes e dominados na hierarquia de desigualdades sociais republicana, urbana e industrial?

Em um estudo já clássico, Azis Simão ressalta o fato de a experiência brasileira de proletarização ter sido feita dentro de uma ordem privada do trabalho, ou seja, dentro "do direito privado de determinar as condições de locação da força de trabalho" (SIMĀO, 1966, p.63). Isto significava que o poder de mando patronal - de dispor da mão-de-obra, estabelecer sua disciplina para os ritmos de trabalho, intensificar e estender a jornada, calcular os montantes salariais, remunerar desigualmente diferentes trabalhadores, punir e dispensar do trabalho, definir e penalizar as transgressões - era exercido de modo tão arbitrário e hierárquico quanto o fora na experiência assalariada que existiu nos interstícios da ordem escravista; a relação de trabalho continuava pautada por instituiçōes de caráter privado apenas "ajustadas" às formulações políticas do Estado liberal. Uma experiência de "ajuste" que se baseava apenas em tratos verbais, sem nenhuma forma semelhante a de um contrato de trabalho com garantias legais. É de se notar que, como norma, esta situação vigorou por mais de 40 anos e que, como situação "informal" de fato, persiste para além da existência posterior da regulamentação trabalhista.

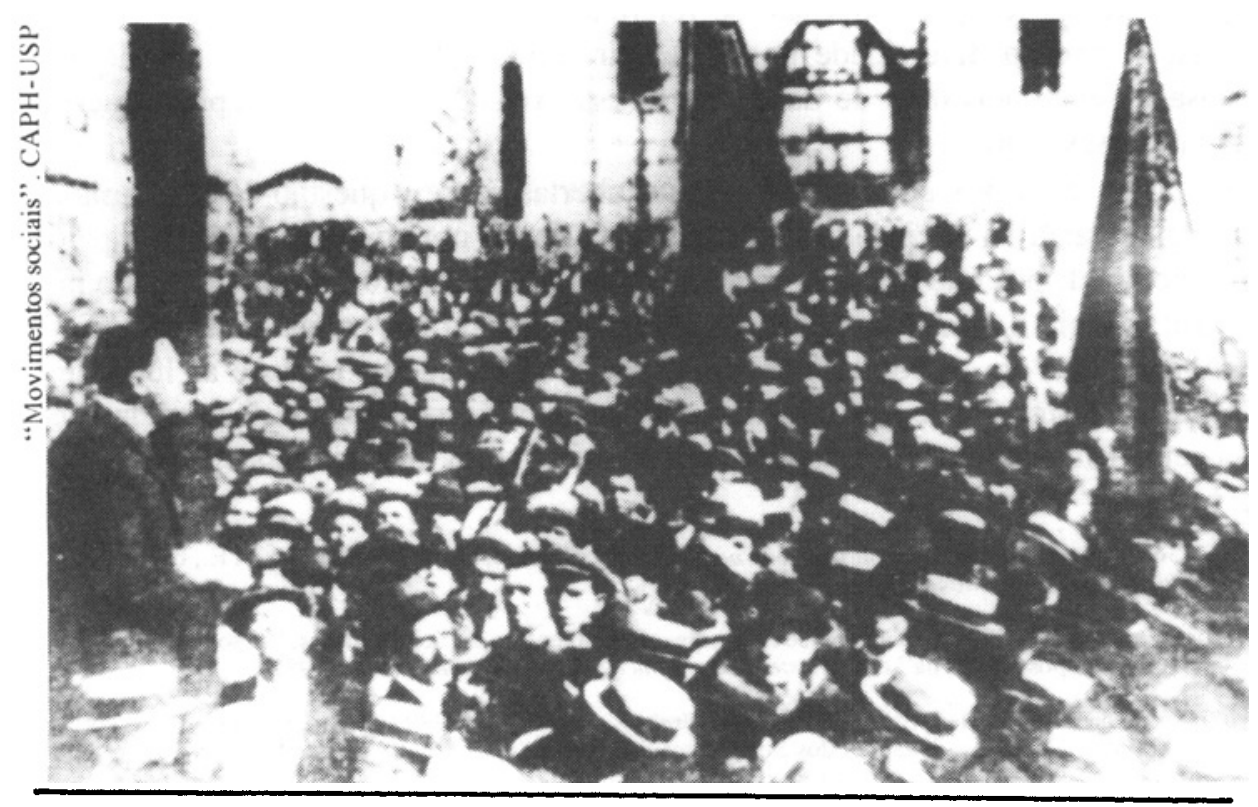


... apesar de a

Republica ter gerado um decreto relativo à condição trabalhadora, (...), nāo so ele era de fato ignorado como convivia com outro, da mesma época (1891), proibindo a "perturbaçâo da ordem pública" atraves de greves.
Esta matriz privada de autoridade, onde homens, mulheres e crianças se tomavam trabalhadores nas décadas iniciais do século, permitiu uma exploração selvagem e dilapidadora de seus corpos e mentes, tendeu a corroer a plausibilidade de suas formas de sociabilidade ordenada e tornou grande parte de suas vidas um espaço de miséria, de violência e de repressão. Todos os documentos que nos chegam desta época - de jornais operários e artigos da grande imprensa, de ensaístas de vários matizes, de visitantes e agentes estrangeiros, de funcionários das parcas instituições governamentais que, sem poder de intervir nas relaçōes de trabalho, as registravam esporadicamente - mostram que sua condição trabalhadora era a de verdadeiros párias, sobretudo a partir do lugar que ocupavam na figuração simbólica da hierarquia de desigualdades sociais. Não aparecem como sujeitos válidos da equivalência jurídica republicana, mas precisamente como pessoas constituídas por um lugar atrás ou fora dela.

Pois apesar de a República ter gerado um decreto relativo à condição trabalhadora, que incidia sobre a proteçāo dos menores na situação de trabalho, nāo só ele era de fato ignorado como convivia com outro, da mesma época (1891), proibindo a "perturbação da ordem pública" através de greves. Ambos os decretos mostram bem a concepção que, mais tarde, seria posta explicitamente pelo pensamento conservador do período: de um lado a proteção de um povo imaturo, sem integração entre si e com o resto da sociedade, sem vocação para a universalidade e incapaz de solidariedade e de açāo coletiva; de outro lado, o perigo que representam quando, em seu protesto, formam a "rale" e a "populaça" sem raízes culturais onde ancorar alguma legitimidade7. A linguagem que descreve as relaçōes de trabalho é inteiramente suficiente para descrever o exercício deste mundo: o emprego aparece como "doação de trabalho" (1897) aos operários, o patrāo como o "chefe da casa" (1901), a greve ou resistência ao arbítrio patronal como intimidação de gente com "má vontade e pouca aplicação", "mal-agradecida" (1901) e disposta todo o tempo a assaltos e violência gratuita. As empresas ameaçam com "avisos humanitários" (1902), readmitem os operários de que precisam "sem ressentimentos" (1906), e prometem "proteger" novamente. A militância e seu recrutamento aparecem na fala policial e patronal como "operários mal aconselhados" (1903) quando nāo como "delinqüentes" (1905) no caso de açōes grevistas bem-sucedidas. Mesmo os organizadores e observadores militantes oscilavam entre a imagem heróica dos trabalhadores e "os cérebros doentios da multidão ignorante" (1912), formada de pessoas "débeis e indefesas". O trabalho de crianças e adolescentes é um ato de benemerência para com os "pequenos hóspedes" da fábrica, impedindo-os de se tornarem delinqüentes ou, no caso feminino, de "abrigá-las de qualquer mau passo" (1917). A luta de classes que se observa nos "outros" países do mundo é "irritante" (1920) e os que a promovem pensam "que são alguma coisa na vida" (1929); quem adere às organizaçōes operárias o faz "inconscientemente" (1929). É inútil multiplicar os exemplos desta linguagem e das relaçōes que ela aponta, abundantemente registradas. Nelas, a classe dominante aceita apenas pessoas diminuídas, constituídas fora da interlocuçāo social e política; e como sujeitos de ação coletiva, são literalmente não-pessoas mas sim "meia dúzia de desqualificados perigosos" (1929). (BEIGUELMAN, 1977; PINHEIRO e HALL, 1981.)

7 Cf. Oliveira Vianna, Populaçöes meridionais do Brasil. Rio de Janeiro. Paz e Terra, v. I e Alberto Torres, A organizaçäo nacional. Sāo Paulo, Cia. Ed. Nacional, 1933. 
Os espaços da cidade ocupados pela população pobre também são visualisados por esta ótica que vê o popular como não-pertinente à ordem social. Quando, em 1916, o prefeito de São Paulo, Washington Luís, propôs transformar a Várzea do Carmo em um parque, sua justificativa enveredou pela necessidade de higienização moral da "vasta superfície chagosa, escalavrada, feia e suja" formada pelas voltas do rio Tamanduateí. Lá, segundo ele:

"protegida pelas depressōes do terreno, pelas arcadas das pontes, pela vegetação das moitas, pela ausência de iluminação, se reúne (...) a vasa da cidade, numa promiscuidade nojosa, composta de negros vagabundos, negras edemaciadas pela embriaguês habitual, de uma mestiçagem viciosa, de restos inomináveis de vencidos de todas as nacionalidades, em todas as idades, todos perigosos. É aí que se cometem atentados que a decência manda calar; é para aí que se atraem jovens estouvados e velhos concupiscentes para matar e roubar (...). Denunciado o mal e indicado o remédio - um parque belo, seguro e saudável - não há lugar para hesitações porque a isso se opōem a beleza, o asseio, a higiene, a moral, a segurança, enfim, a civilização e o espírito de iniciativa de São Paulo". (WASHINGTON LUís, Relatório, $1^{\circ}$ volume.)

Qual o mundo que se abriga nesta linguagem? Parece claro que, nele, a desigualdade de fato é aceita e praticada às claras, no sentido de os direitos modernos serem prerrogativas da classe dominante; um sistema onde a cidadania continua a ser privilégio dos senhores (ADORNO, 1981) ${ }^{8}$, sendo o seu o mundo válido publicamente, mesmo que agora portassem a identidade de "homens de negócios", como os industriais gostavam de se representar. Ao que tudo indica, este horizonte simbólico encontrava consenso moral também nas classes médias; um horizonte simbólico que despachava os trabalhadores pobres a um mundo do favor, da dependência, da hierarquia excludente; uma figura que, para ser incluída na ordem das coisas, necessitava ser um habitante silencioso e sem interioridade, constituído por obra benemérita das elites. Por isso eles podiam agüentar relaçōes de trabalho regidas pela vontade pessoal do patrão, que deixa à mostra um ciclo repetitivo exasperante. Por exemplo, reduzir o salário por acúmulo de estoques ou retração de mercado. Ou aumentar a jornada por demanda deste mesmo mercado. Ou intensificar a produção - ou ao contrário - e em todos estes casos manter o salário a despeito de extorquir mais trabalho; ou abaixá-lo a despeito de manter sua extensividade ou intensividade. Algum tempo se passava e os trabalhadores, revoltados mas temerosos de perder o emprego, esperavam que a produtividade mercantil da fábrica repusesse suas perdas. Nada acontecia, mesmo que a fábrica superasse suas dificuldades econômicas. Estoura a greve. Subverte-se o chão da fábrica, seçōes ficam vazias, ecoam palavras de indignação. Nos portōes, os piquetes. A polícia os dispersa, prende os líderes. Patrōes contratam outros trabalhadores sem emprego para substituir os grevistas. Amedrontados, os trabalhadores em greve voltam ao trabalho. A polícia libera ou some com os líderes. A fábrica, conforme suas necessidades, cede um pouco ou não cede nada. Quando admite alguma melho-

8

A noção do "senhor cidadão" como parâmetro da cidadania na sociedade patriarcal brasileira $€$ de. Sérgio Adorno. Cf. também Maria Celia Paoli, "Mulheres: lugar, imagem, movimento" em Perspectivas Antropologicas da Mulher. n. 4, Zahar, 1985.
Decifrar uma sociedade que evitou colocar a questāo da cidadania e da democratização diante da heterogeneidade de sua instituição social moderna implica em perceber o lugar que abriu para a representação de suas classes populares... 
ria, esta deixa logo de ter vigência caso seja da conveniência dos patrōes. Cada vez mais, as fábricas se enchem de mulheres jovens, crianças raquíticas, turnos dobrados, mestres grosseiros, mais máquinas, mais matérias-primas. Cada vez mais os salários eram atrasados, pagos por produção e não remuneravam as horas-extras. Numa palavra, os trabalhadores eram penalizados no sucesso ou no insucesso fabril. Algum tempo depois, nova greve, exasperada, propunha de novo outra definição para o lugar de seus trabalhadores neste sistema. E o ciclo recomeçava, nas palavras de Beiguelman (1977): "ciclo de efervescência e repressão".

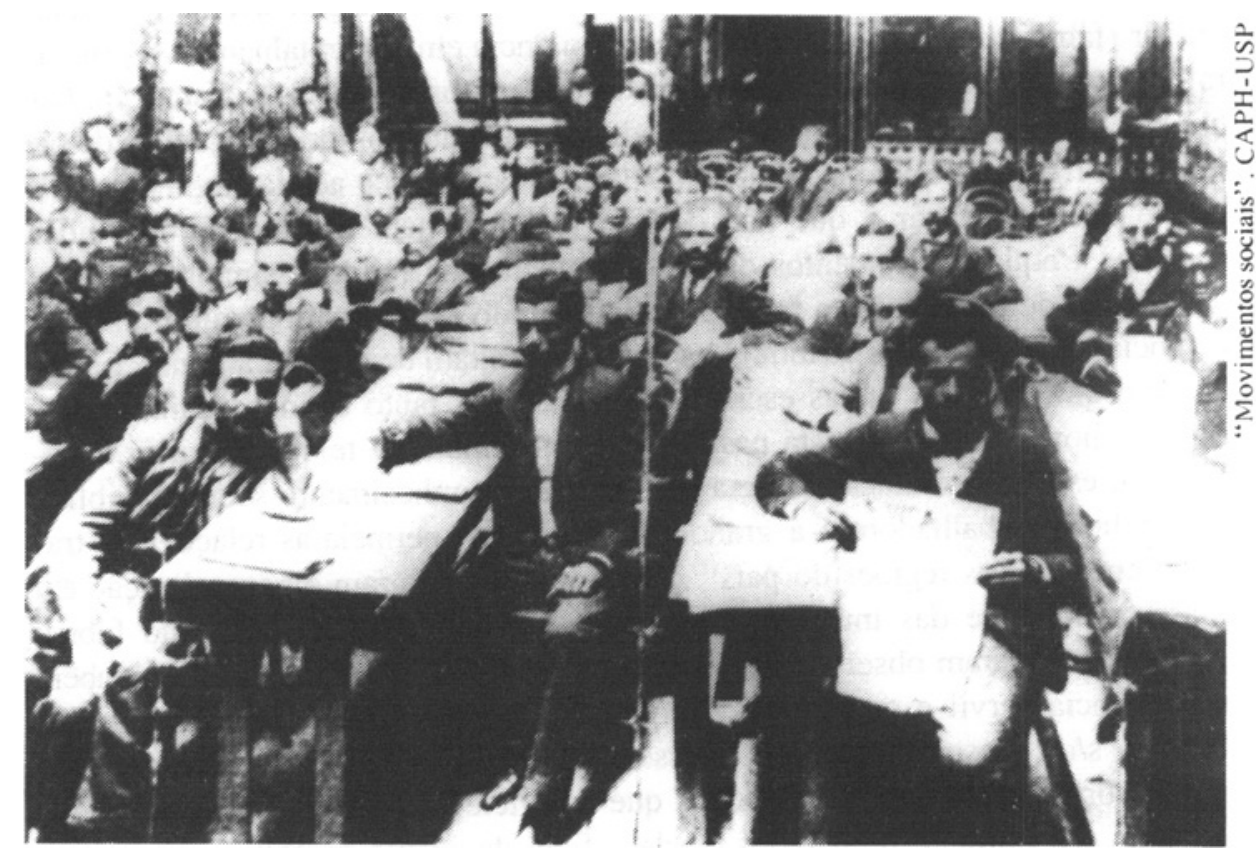

As uniōes, associações, sociedades, alianças, ligas de resistência e mais tarde sindicatos são a força ampliada e expressıva dos grupos de fábrica para responder a este mando privatizado e unilateral dos patrōes. Mas são tão intermitentes quanto as greves e os grupos fabris que se formam e se desfazem a cada rebeldia. Elas procuram, no entanto, uma permanência no protesto que a própria dinâmica da greve não permite. E esta permanência foi primeiro achada pelo lado moral e ético do trabalho urbano e industrial, exatamente naquilo que o capitalismo dilapidador e aristocrático despreza. Pois os patrōes homogeneizavam qualquer trabalho manual e confundiam o proletário com o pobre, percebendo o trabalhador apenas através de suas necessidades imediatas. Por perceberem dessa forma, pedem também sua submissão conformada a regras unilaterais. Contra isso estáo as greves, mas, além delas, formam-se ligas por ofício que afirmam o orgulho de um trabalho com saber próprio. Os anarquistas, que tão bem souberam interpretar este sentimento (mesmo que formulando-o a partir de outra matriz, a transição européia do artesão ao proletário, quase inexistente no Brasil) fizeram uma contraposição ideológica à cabeça senhorial dos patrôes brasileiros: santificaram o gesto cotidiano do trabalho, atribuindo-lhe um valor intrínseco de dignidade, liberdade e inteligência. Lembravam aos trabalhadores um outro percurso para este gesto, traçado no reverso das relaçōes de mando fabris. 
A imprensa operária montou a publicidade deste outro horizonte de referência interpretativa. A cada relato das greves que noticia, a cada desmando do governo que critica, a cada artigo doutrinário e teórico que reproduz, a cada poesia que publica9, esta imprensa elabora a categoria de dignidade como o centro da condição proletária e, através dela, costura os traços comuns de proletários muito diferentes.

Mas parece que, quanto mais esta imagem é elaborada, mais a ordem dominante insiste no ancoramento negativo da figura dos trabalhadores nesta mesma ordem. Duas práticas a representam bem: a homogeneização do trabalhador (fabril e urbano) como pobre e a violência em seu tratamento. A primeira vê a populaçāo como um espaço plano onde pobres genéricos transitam: humildes, eles são merecedores de caridade, assistência e favor, mas jamais de direitos. A figura de trabalhadores como "pés rapados" que aceitavam o quanto o patrão quisesse pagar e que não deviam reclamar nem das taretas atribuídas nem dos freqüentes aumentos das horas trabalhadas fundava simultaneamente uma noção de trabalho sem face, posto no mundo apenas para garantir a sobrevivência de pessoas sem atributos que nāo necessitam de certeza alguma. É uma imagem que está nas linhas escritas por industriais tanto sulinos quanto os senhoriais nordestinos; que está nas linhas e entrelinhas de textos literários e, sobretudo, está na correlação entre a ausência de reconhecimento sócial e público da condição trabalhadora e a grande violência que permeia as relaçōes de trabalho em todas as regiōes do pais ${ }^{10}$. Historiadores notaram a generalização e a quase trivialidade das inúmeras "pequenas" brutalidades no cotidiano fabril, que impressionaram observadores (externos) dos mais diversos tipos; e também a arrogância servil e os abusos de policiais "em sua relação com os pobres" (HALL, s/d), mesmo que não houvessem perturbações na ordem pública ${ }^{11}$. Os atos de brutalidade contra "cidadãos que a polícia não gosta", tão conhecidos até hoje, sāo portanto registrados desde o final do século passado e completam o quadro do paternalismo privativista, da assistência benemérita e da inoperância de regulamentos contratuais. Da figura do trabalhador pobre, comum, criminalizável por princípio, até as repressões violentas contra as tentativas de organizaçāo e açāo coletiva de protesto operário - de resto, necessariamente explosivo como forma de aparecimento (mesmo que não o fosse como prática) surge um retrato de sociedade questionada pelo transbordamento de suas fronteiras de consenso e de conflitos regulamentáveis, pelos inéditos reclamos de inéditos direitos sociais. É uma sociedade que se mostra simultaneamente frágil e dura, conciliadora e violenta, desinformada e embusteira naquilo que quer ouvir e reconhecer como parte de seu espaço comum.

Uma sociedade, portanto, onde o campo de luta principal parece ser o dos direitos de reconhecimento, representação e negociação dos trabalhadores como

9 Sobre a produção cultural dos anarquistas, cf. Foot Hardman, Nem pátria, nem paträo. São Paulo, Brasiliense, 1983.

10 Sobre a atitude dos empresários e suas idéjas a respeito do trabalhador, cf. Pupo Nogueira, $A$ indristria em face dus lets do trabalho, São Paulo, Escolas Profissionais Salesianas, 1927 e CIFTA-RJ, "Inquerito sobre horário de trabalho na indústria nacional de fiacáo e tecelagem", janeiro de 1931. Sobre a violência como padrão recorrente na experiência de proletarizaçăo, ver Michael Hall, On wi. dening the scope of Latin American Working-class history: some general considerations and a brazilian case study. s/d (mimeografado).

11

Sobre a criminalidade no cotidiano da cidade de São Paulo, ver Boris Fausto, Crnme e cotidiano. A criminahdade em São Paulo, 1880-1924. Brasiliense, 1984.

\section{A figura de}

trabalhadores como

"pés rapados" que

aceitavam o quanto o

patrâo quisesse pagar e que não deviam

reclamar nem das

tarefas atribuídas nem

dos freqüentes

aumentos das horas

trabalhadas fundava

simultaneamente uma noção de trabalho sem face... 
classe, cujas alternativas institucionais de controle e de consenso têm que se dar sobre uma outra figuração da vida popular e de sua presença. É nesse sentido que as revoltas fabris localizadas, as pequenas greves que se repōem intermitentemente, mas teimosamente, em cada empresa e as incipientes, mas reais, tentativas de organização operária no chão da fábrica adquirem simultaneamente dois aspectos fundamentais: elas se tornam realmente incontroláveis em sua repetiçāo exasperada; $e$ elas tematizam e revelam, na prática, uma sociedade onde a ausência de direitos torna implausível o projeto de modernidade. Ou seja, cada revolta é o ato, renovado, onde os trabalhadores tomam posse do seu lugar positivo diante de uma ordem social que não os acolhe, e é no confronto que fazem sua experiência positiva do social.

Talvez por isso a busca da condição de cidadania se expressou como questâo social cujo fundamento passou a ser uma concepção de sociedade justa. O espaço público de representação passa a ser enunciado (por ações operárias e não-operárias) como a realização de uma justiça social que recupere aqueles que a merecem mas não a têm, como garantias legais válidas.

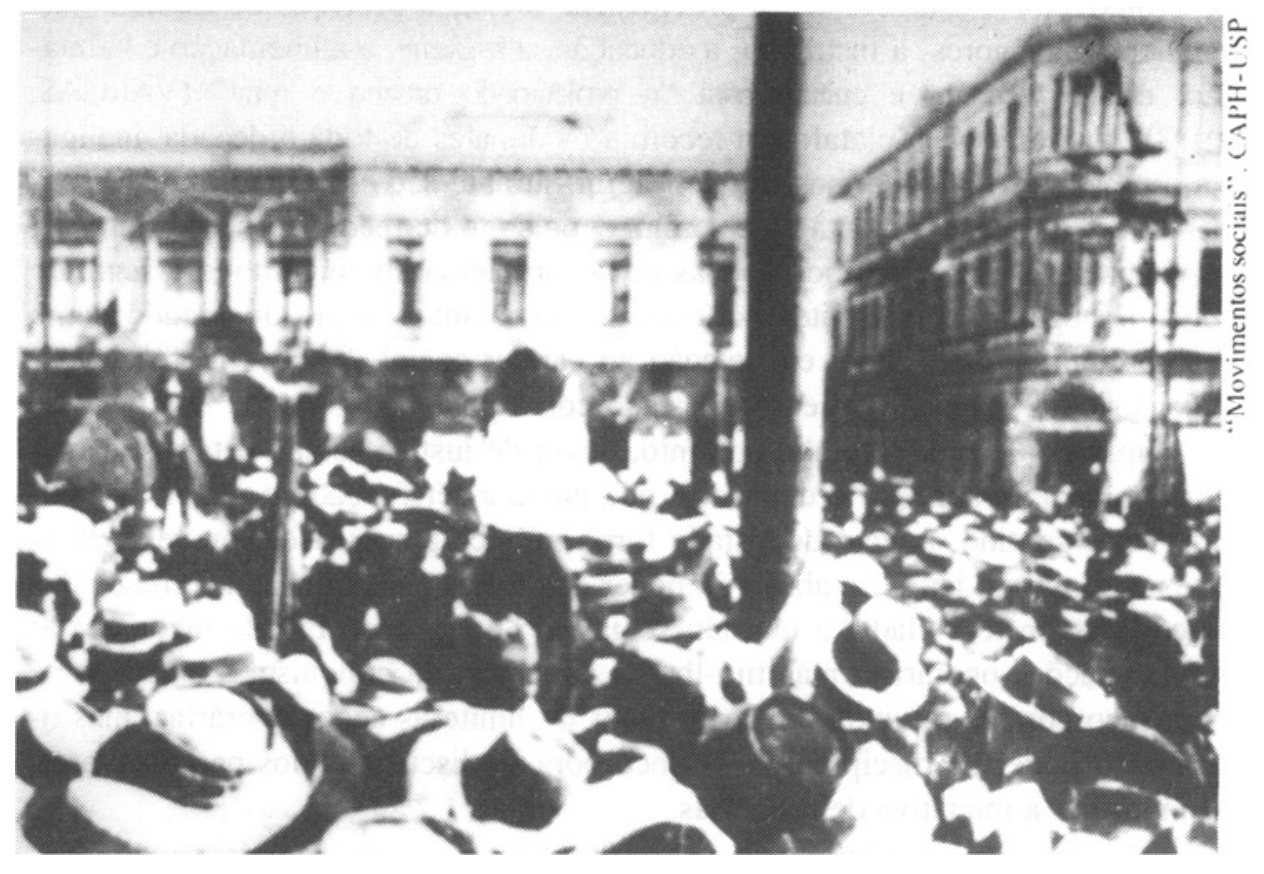

Os Direitos do Trabalho: a figura pública

Nunca é demais insistir que a necessidade destas garantias legais para imprimir todo um outro funcionamento às relaçōes sociais de trabalho e também para resolver a questão da participação política popular estava no horizonte de todas as forças colocadas em movimento nos anos 20 . Inclusive no horizonte das lutas operárias, mesmo com a sua explícita negação ideológica do Estado. Como diz Munakata, a luta operária "começa a escapar dos limites de cada empresa e de cada categoria. Quanto mais genéricas e generalizadoras tornam-se as reivindicaçōes, mais elas acabam tendo como alvo o Estado" (MUNAKATA, 1981, p. 28). A garantia estatal da paz social, através de uma igualdade contratual coletiva que limitasse privilégios e impusesse direitos sociais no plano público, 
estava nas notícias dos jomais, nos escritos dos ensaístas, nos projetos dos políticos, nas revoltas militares, no cálculo dos empresários e nas lutas operárias por uma parcela do poder. A situação na década de 20 é peculiar e ambígua: todos pedem um tipo de iniciativa geral que envolva a reorganização da sociedade, mas a perspectiva política de encaminhá-la está impregnada de uma fórmula profundamente autoritária, a da imposiçâo de uma "democracia social" por um poder centralizado. Esta é uma opção de mão única na luta geral contra o capitalismo liberal e é o que promove a adesão a projetos formalmente tão diferentes como os movimentos comunistas, fascistas e militares da época.

Nas semanas que precederam as eleiçōes presidenciais de 1930, o "entusiasmo popular, espontâneo, vivo, ruidoso" com que eram acolhidas as caravanas da Aliança Liberal, segundo palavras de Pimenta (1949, p. 395), talvez expressassem o crédito em uma renovação do poder, delineada na plataforma eleitoral lida pelo candidato da oposição, Getúlio Vargas, em janeiro de 1930. Nela, reconhecendo que "as classes populares são as que sentem com mais nitidez a necessidade de modificação política", Getúlio Vargas prometia a ação rápida e tutelar do Estado na feitura de um Código do Trabalho. Através dele se promoveria a estabilidade, a previdência social, a proteção do trabalho das mulheres e menores, a instrução, a educação, a higiene, a alimentação e habitaçāo, crédito, esportes e cultura para "o proletariado urbano e nural" (VARGAS, 1938). Na verdade, a plataforma recolhia os debates de toda a década, inaugurados em 1917, cujos termos iria consagrar durante seus 15 longos anos no poder. Estes termos eram então - e seriam depois - o de reconhecer os direitos de participação social e política apenas como problema administrativo e legal do Estado, negando-lhes caráter político; propor a intervenção do Estado como responsabilidade do poder em relação ao caráter social, físico e moral da população trabalhadora; conceber o Estado como poder que "acode" os fracos e desamparados, sendo a tutela, portanto, dever de justiça social; esta justiça social promove uma nação ordenada, o que passa a ser função do poder de Estado. Neste sentido, a ação do Estado torna pública a sociedade, prevenindo as lutas e conflitos, isto é, o abuso do poder dos fortes e a explosão irrefreada dos fracos. Assim formulada, a questāo social sob a égide do Estado incorpora as reivindicaçōes operárias, mas tira-lhes a dimensão da conquista e o espaço de luta; incorpora as reivindicações patronais de limite às ações operárias, mas tira-lhes o poder de discipliná-las; e incorpora as discussões dos parlamentares, tirando-lhes a iniciativa de propô-las.

Assim, o golpe militar de outubro de 1930 iria levar, para dentro do Estado, as demandas sociais nascidas das relaçōes de trabalho e durante 30 anos levadas como luta entre os trabalhadores, os patrōes e a sociedade. $O$ novo aparato de Estado iria pressionar o capital para se entender consigo mesmo, para reconsiderar as formas de sua imposição e para ressituar as relaçōes com os trabalhadores. Ao mesmo tempo, imporia o desentendimento do operariado consigo mesmo, ao se colocar no vértice da luta de classes como luta pelos direitos de existência social que descortina uma sociedade democrática, invertendo precisamente este seu sentido. Tudo aquilo que havia sido formulado pelo movimento operário em sua experiência no espaço capitalista de produção foi aspirado por este novo Estado, e nele foram sufocadas as formas de organização e combate até então levadas. Mas as questões do direito ao trabalho; da luta pelas condições coletivas de trabalho; da luta pela apropriação do tempo de trabalho
... o golpe militar de outubro de 1930 iria levar, para dentro do Estado, as demandas sociais nascidas das relaçōes de trabalho e durante 30 anos levadas como luta entre os trabalhadores, os patrōes e a sociedade. 
e da luta pela remuneração digna do trabalho iriam ser continuamente repostas na experiência cotidiana de proletarização, reaparecendo pelos poros de uma sociedade controlada. O novo Estado, apropriando-se da relação estabelecida pelo movimento operário entre fábrica, direitos sociais e sociedade, esvaziaria a reivindicação de representação pública autônoma que nela existia. A lembrança, no entanto, seria cultivada porque a fábrica a repunha todo o tempo, embora recoberta pelo brilhante discurso dos novos dispositivos legais sobre os direitos trabalhistas. Dentro disso, iria se desenvolver a história dos trabalhadores no mundo político montado para a implantação do capital industrial, como projeto dominante dos novos tempos.

Entre 1930 e 1934 o governo concretizou este projeto, criando um aparato de Estado especialmente destinado a mediar e a referenciar estas lutas de classes por existência pública e política que se desenrolavam no espaço capitalista da empresa industrial. Sua implementação foi um processo longo e indeterminado, disputado palmo a palmo por trabalhadores, patrões e governo, em acontecimentos onde a tentativa de construção, por cada um dos agentes, de uma autoridade legítima para si se mistura com a repressão violenta dos mais fortes e sua fala desqualificadora e com a organização da ação dos trabalhadores, basicamente falando a linguagem das greves na luta pela autonomia e pelos direitos. Como já tive ocasião de mencionar em outro texto ${ }^{12}$, a linguagem das greves constrói uma outra versão não só dos direitos mas também das bases sobre as quais se assentava a produtividade industrial do País, o que punha em xeque a fragmentação burocrática operada pelo Estado ao dar-lhes enunciação legal.

É esta articulação das reivindicações dos trabalhadores, cada vez mais desenvolvidas diante da legalização de suas demandas como direitos, que ancora na fábrica uma experiência coletiva de classe com possibilidade de ser generalizada. $\mathrm{O}$ reconhecimento dos direitos sociais dos trabalhadores apontava, portanto, para o reconhecimento da classe como parceiros na formulação das políticas sociais e econômicas que o País começava a esboçar. Os novos grupos que ocuparam o poder do Estado (para não falar dos antigos que não foram desalojados) não tinham a mais remota intenção de abrir tal espaço. As muitas lutas que se davam nos diversos lugares de trabalho e de vida coletiva da sociedade eram ameaçadoras, mas não a ponto de modificar o projeto de fazer do Estado (e de sua burocracia) o agente único de um sistema menos desigual. Frente àquilo que os movimentos dos trabalhadores sugeriam - a transformação da sociedade (e de sua radical desigualdade) por movimentos apegados à sua experiência -, o Estado vai pouco a pouco se dotando do caráter de poder pleno, que lança mão de diferentes recursos legais e coativos para deter o direito de decisão sobre os temas levantados pelas reivindicaçōes dos trabalhadores.

Além disso, estas greves parecem ter representado um estímulo à necessidade de melhor organização sindical, e várias categorias de trabalhadores empenharam-se em construí-la. Foi, portanto, diante da promessa de um sindicalismo autônomo, alimentado por auto-organizaçōes fabris e questionador do modelo de exploração vigente que o governo foi aprendendo a se constituir como uma gestão centralizada da questão social.

12 Maria Celia Paoli, "Os trabalhadores urbanos na fala dos outros". Em Leite Lopes, org. Cutura c identidade operária. Marco Zero, 1987. 


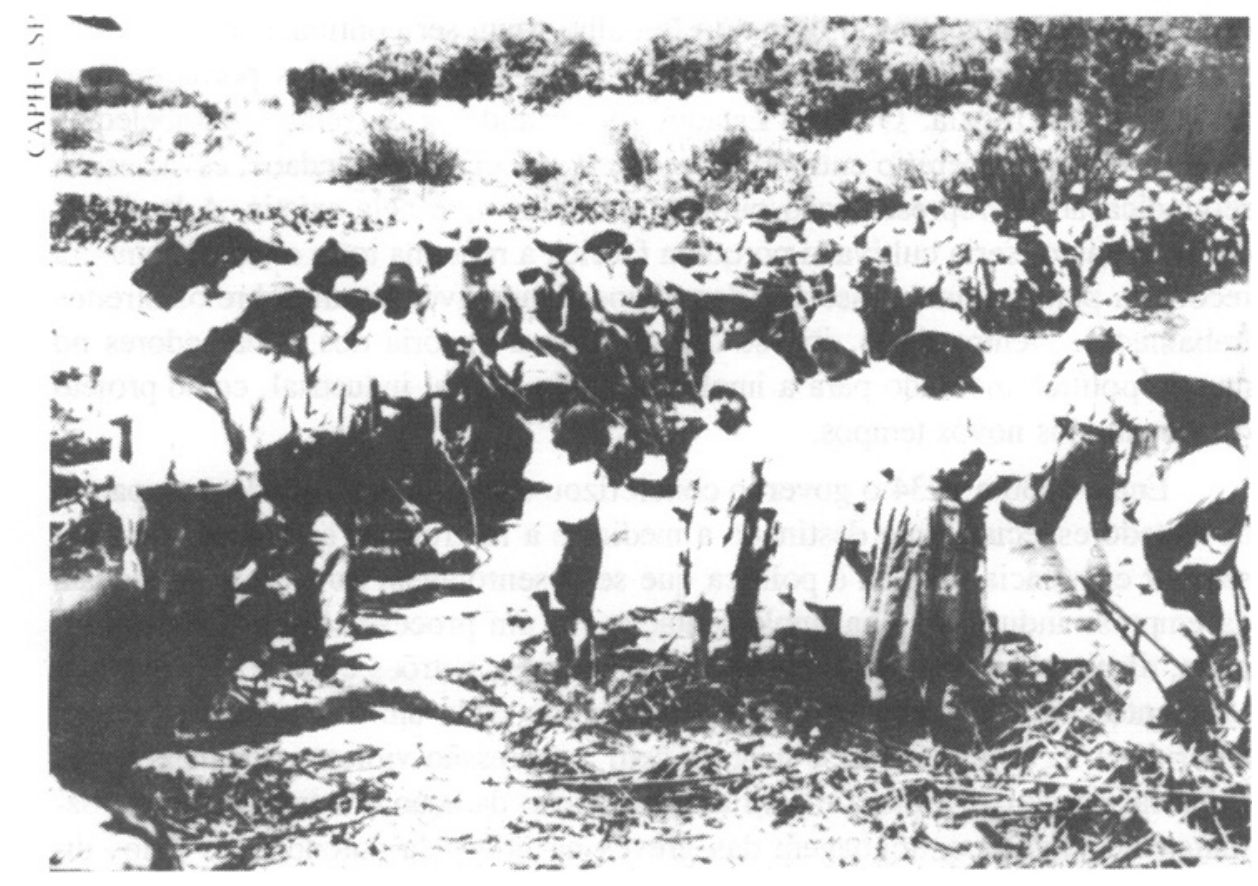

As reivindicaçōes ligadas ao cotidiano fabril dos trabalhadores supunham, para sua efetiva vigência, a constituição de um espaço de negociação política entre patrōes e operários. Isto suporia uma organização operária com legitimidade e capacidade de representação efetiva, ou seja, de poder. Independentemente da capacidade real do movimento operário em construi-la, a atitude do governo foi, de antemão, a de procurar destruir esta possibilidade. Os anos que vão de 1932 a 1935 testemunharam a história desta destruição de um poder operário autônomo, ação levada pelo governo através da Legislação Sindical. A história da implantação desta legislação $\hat{\epsilon}$, também, uma história feita em pedaços: o governo apóia-se sobre alguns interesses operários mas não em outros; afirma-se explorando as divisōes internas no interior da classe; concede vantagens e prejuízos ao propor medidas de controle sobre o mercado, tais como o cadastramento dos trabalhadores (carteira de trabalho, passaporte de seus direitos sociais); a estabilidade de emprego; um sistema previdenciário e, sobretudo, quando propõe um sistema de julgamento dos dissídios (Juntas de Conciliação e Julgamento, futura Justiça do Trabalho). A cada vez o Estado aumenta mais a sua própria autonomia, apropriando-se, também cada vez mais, dos temas de luta operária.

Justamente este direito de vida coletiva e diferenciada foi lutado - e perdido - na década de 30, por diferentes grupos sociais, mas sobretudo por trabalhadores. Todas as questōes mais importantes para a configura ção de uma sc ciedade urbana e industrial moderna - aspiração colocada explicitamente pelo novo poder de 1930 - haviam sido colocadas pelos movimentos de trabalhadores; e foi a forma de resolvê-las, sugerida por sua. rebeldia, que fez o governo legislar tāo rapidamente sobre elas. Em quatro anos, afinal, as questōes do emprego e desempego, trabalho das mulheres e crianças, ferias; descanso semanal, limitação da jornada de trabalho, condiçōes de trabalho, limitação da disciplinā empresarial no tocante à intensidade do trabalho foram transformadas em leis do Estado e critérios de organização da sociedade. Por outro lado, o direito à 
sindicalização foi sendo transformado em meio de identificação entre poder, lei e sociedade, de modo que a capacidade de auto-organização social - sugerida basicamente pelos movimentos operários organizados - fosse disciplinada, regulada e vigiada; em outros termos, ficasse em um espaço público legalmente autorizado e portanto reduzido e cristalizado. Isto pode ser visto, com clareza, na forma de funcionamento das leis sociais durante estes anos.

Havia na Legislação Sindical de 1931 um dispositivo certamente assustador: ele atribuía aos sindicatos operários poderes de fiscalização das condiçōes de trabalho, podendo estes requerer ao ministério no caso de burlas em relação ao horário de trabalho (principalmente para mulheres e crianças), ao salário igual para trabalho igual e à higiene do trabalho nas fábricas, oficinas, casas de comércio, usinas. Além disso, os sindicatos poderiam também requerer ao ministério medidas contra infraçöes de leis que garantiam seu próprio direito sindical (artigo $8^{\circ}$ ). $\mathrm{O}$ artigo $13^{\circ}$ reforçava este poder sindical, proibindo os patrōes de despedir, suspender e rebaixar de categoria, salário e ordenado o trabalhador sindicalizado ou aquele que tivesse, no seio de seu sindicato, "manifestado idéias ou assumido atitudes em divergência com seus patrōes".

Talvez mais rapidamente que o próprio movimento operário (que recusava in totum a sindicalização oficial $e$, portanto, suas eventuais vantagens) os patrōes viram que estes artigos sugeriam a figura do delegado sindical, "capazes de aconselhar greves ou desobediências aos regulamentos internos das empresas" e trazendo "o aniquilamento da autoridade, da hierarquia e da disciplina indispensável em qualquer organizaçāo" ( Federaçāo Industrial do RJ apud CASTRO GOMES, 1979, p. 242), como explicava o relatório da comissão especial formada pelo Centro Industrial do Brasil para analisar o decreto. Afirmavam ar que deveria ser "expressamente proibida a existência de representantes sindicais operários nos locais de trabalho" e sugeriam que todas as questōes fossem tratadas somente nas sedes dos sindicatos (id. ibid.). A luta empresarial contra o poder operário de interferir nas questōes relativas ao trabalho fabril aparece também em São Paulo, e não só nas circulares e relatórios internos às associaçōes empresariais. Os jornais estampam entrevistas onde os empresários declaram, por exemplo, que "o que não se compreende é que eles (os trabalhadores) desejem que nos lugares onde trabalham existam representantes seus, com voto nas deliberaçōes dos patrōes. Dessa forma, um operário não poderá ser despedido sem previa consulta aos representantes de classe. A predominar este critério, então, não haverá mais disciplina e muito menos trabalho eficiente" (Matarazzo apud LEME, 1978, p.146).

De 1931 a 1934, os empresários rejeitam sistematicamente o poder contratador e fiscalizador dos sindicatos operários. No caso da lei dos contratos coletivos de trabalho, já referida, rejeitam que as tabelas salariais possam ser negociadas no plano sindical e muito menos que tais ajustes possam valer para toda uma categoria profissional regional. A Federação das Indústrias do Estado

Os anos que vão de 1932 a 1935 testemunharam a hist6ria desta destruição de um poder operário e autónomo, açăo levada pelo governo através da Legislação Sindical. de São Paulo (FIESP) afirma que "se é verdade que no regime individual o patrão pode explorar impunemente, é também verdade que no regime de imposição dos sindicatos o resultado será o oposto a este" (FIESP, 1931). Quando a lei sobre acidentes de trabalho é reformulada, em 1934, e nela também está prevista a fiscalização do seu cumprimento por parte dos sindicatos operários, os industriais batem na mesma frase: "prejudica o princípio de autoridade e disciplina dos estabelecimentos industriais" (FIESP, 1934). O mesmo refrão é 
utilizado quando saiu finalmente a lei de férias - Lei n²3.768, de 18/1/1934. Ela especificava claramente que "as federações regionais e, na sua falta, os sindicatos de classe, por intermédio de representantes devidamente autorizados pelo Ministério do Trabalho, possam verificar a existência de infraçōes e lavrar os respectivos termos" (artigo 23).

Talvez os empresários industriais não tivessem muito a temer por parte do movimento operário, porque este já havia escolhido outra linguagem - que não a lei - para expressar sua intenção de disputa pelo espaço da fábrica e pelo mercado de trabalho: as greves. Para alguns setores mais influentes do movimento operário organizado, era importante manter a qualquer custo uma política independente para os sindicatos operários e fizeram uma rejeição em bloco das leis promulgadas pelo Estado, tanto aquelas que obviamente iam contra sua autonomia organizativa (Legislação Sindical) quanto aquelas que eram simples respostas às suas tradicionais reivindicaçōes. Outros setores, sem abrir mão da prioridade das greves, resolvem apoiar e pressionar o trabalho legislativo social do governo: exigem a regulamentação imediata das leis promulgadas e também novas leis. Mas embora se fizessem presentes até nos sindicatos oficiais, e falassem na necessidade dos sindicatos fiscalizarem a aplicação das leis emitidas, nāo há sinais encontrados que indiquem uma discussão avaliativa das brechas possíveis que a lei abria. Os sindicatos ligados ao PC, por exemplo, estavam mais interessados em deter as divisōes internas do movimento (agravadas diante da questão das diferentes posturas frente ao governo) e afirmar o princípio da unicidade sindical; de modo que as lutas pelas reivindicações diretas do cotidiano operário se tornam secundárias diante da tarefa, que lhes parecia mais importante, de centralizar o movimento e inseri-lo nos grandes temas do conflito político-institucional em curso (por exemplo: lutar contra o integralismo).

O debate sindical e político do período mostra, sem dúvida, o lado mais dramático da luta pela autonomia sindical diante das leis que o transformavam em órgão do Estado. Mas a possibilidade de organizar a base dos trabalhadores em relação à sua condição operária e à própria organização da produção - exatamente o lugar onde as leis trabalhistas entravam - ilumina o outro lado deste drama, porque aí se constituía o espaço e a definição dos "trabalhadores cidadãos" que o governo empreendia. A chance de organizar esta base não vinha, evidentemente, de posições de princípio doutrinárias, mas da possibilidade de os sindicatos autônomos manterem uma prática presente e próxima do cotidiano da exploração operária. A resistência patronal era violenta exatamente neste ponto: não admitia abrir mão nem do seu domínio real na fábrica nem no mercado de emprego. Embora grupos organizados de fábrica fossem uma prática conhecida e acionada pelos trabalhadores em greves, nâo há muitos sinais que indiquem a sua redefinição (para além dos momentos da greve) diante da presença das leis sociais no próprio espaço fabril. Talvez por isso, a sugestão de que a lei fazia os trabalhadores se tornarem quase fiscais da legislação não tenha mobilizado os sindicatos.

Certamente o movimento operário tinha plenas razōes para rejeitar tal possibilidade, dado que cada vez mais a vinculação entre direitos sociais e subordinação organizativa sindical configurava uma burocracia estatal forte que quebrava toda a chance de uma ação independente. A própria formulação das leis era parcial e ambígua como mostra Castro Gomes (1979, p.245). Embora se
A luta empresarial contra o poder. operário de interferir nas questōes relativas ao trabalho fabril aparece também em São Paulo, e não s6 nas circulares e relatorios internos às associações empresariais. 
saiba que os anteprojetos de lei eram enviados aos sindicatos antes da sua promulgação, o material documental disponível mostra apenas a participação patronal em sua feitura. A marca operária é também quase ausente das comissões paritárias formadas freqüentemente pelo MT para discutir estes projetos - e $\varepsilon$ possível que a maior parte dos nomes que o Boletim do Ministério do Trabalho cita quando noticia o trabalho de alguma comissăo sejam meramente prepostos da própria burocracia interna do ministério.

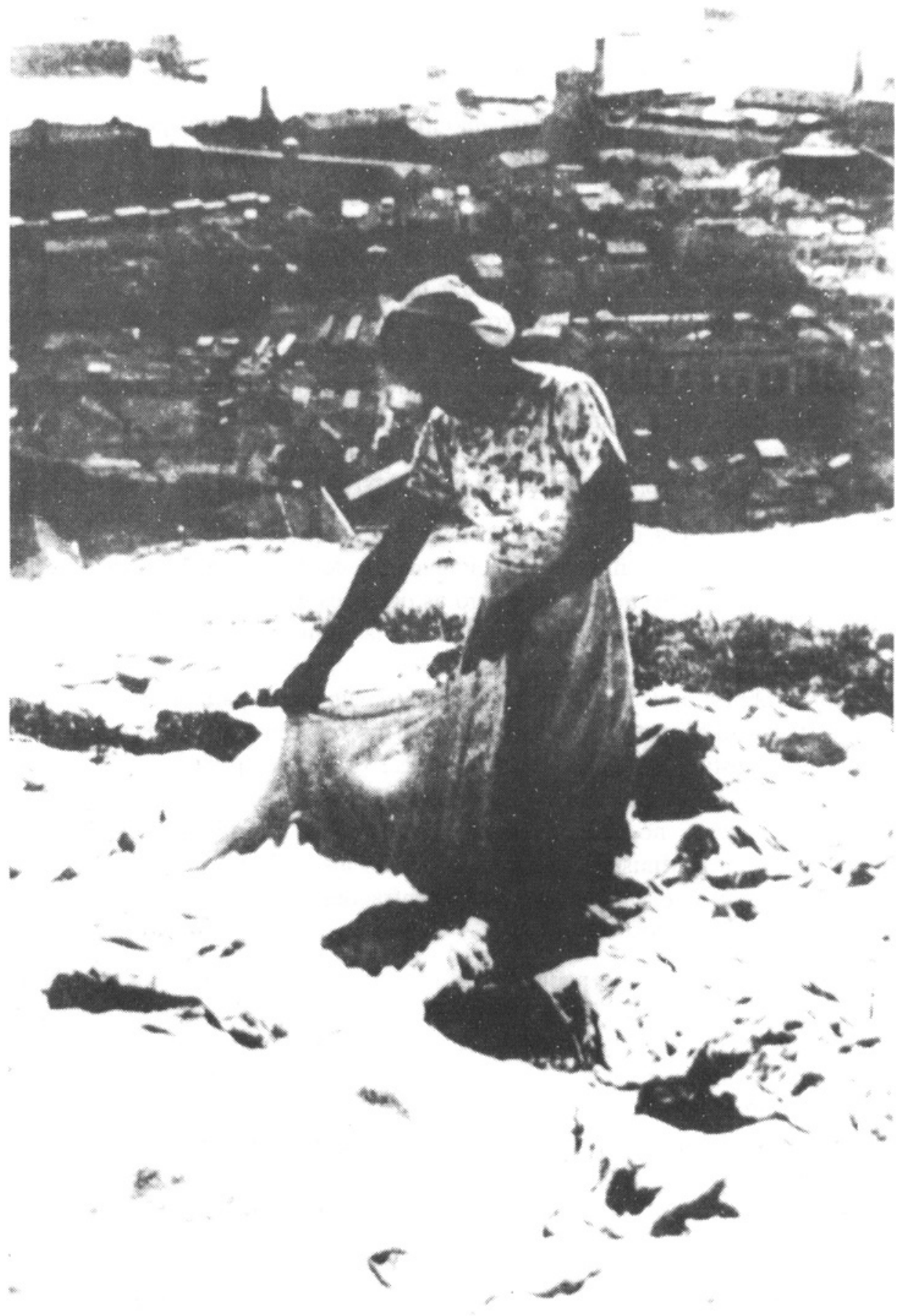


Em compensação, os empresários estavam presentes em quase todos os passos da elaboração das leis. Em certos casos, marcaram com tal força seus interesses que o próprio texto da lei impedia a vigência dos direitos que formalmente assegurava. Esse é exatamente o caso das convençōes coletivas de trabalho e das juntas de conciliação, tornadas facultativas - de modo que, se as partes não chegassem a uma conciliaçăo, o conflito ficava sem decisão (CASTRO GOMES, 1979, p.235). Mesmo para os poucos e raros acordos de trabalho noticiados - que contêm alguns pontos importantes para os trabalhadores envolvidos - não há a menor garantia que seriam respeitados. A não ser, provavelmente, para aquelas categorias com controle do processo de trabalho e do mercado de emprego - como é o caso de duas das convençöes mencionadas, que se referem ao setor de construção civil (BMTIC, 1934, p.298).

O proprio Ministerio do Trabalho mobilizava seus juristas para interpretar as leis para os sindicatos, ou seja, para desdizer tudo o que a lei parecia dizer. Assim, por exemplo, quando o Sindicato dos Bancários encaminhou um processo em que estava em jogo a sua capacidade legal de fiscalização das leis sociais, o mais famoso consultor jurídico do Ministério, Oliveira Vianna, apressou-se em dizer que "o poder de entrar nos locais de trabalho a qualquer hora do dia e inspecioná-los é privativo das autoridades do Estado. Indivíduos privados, vítimas das infraçōes às regras, e suas associaçōes de classe, apenas têm o poder de denunciar e fazer acusaçōes às cortes (...) e nada mais. Os representantes sindicais podem apenas relatar violaçōes flagrantes da lei que eles próprios testemunharam (...). Todas as açốes não-flagrantes estão fora da ação de supervisão dos inspetores sindicais" (VIANNA, 1934, p.129-131).

No mesmo dia em que saiu a nova Legislaçāo Sindical, 12 de julho de 1934, o governo organizou o funcionamento do Departamento Nacional do Trabalho, órgão que tinha a seu cargo as questōes de sindicalização e conflitos de trabalho. Nele foi organizada uma seção administrativa especialmente para inspecionar e fiscalizar o cumprimento das leis trabalhistas, além de fazer inquéritos sobre a proteção e prevenção dos trabalhadores para propor novas medidas. Como o Ministério não tinha disposição ou recursos para fazer do novo órgão uma instituição atuante nacionalmente (a não ser para o controle sindical), acabou delegando sua atividade fiscal a órgãos regionais já existentes - de modo que apenas no Rio de Janeiro o serviço de fiscalização se vinculava realmente com o Ministério. Eram seus os fiscais que tinham o "poder de penetrar os estabelecimentos para verificar infraçōes", negado aos delegados sindicais pelo relator jurídico.

Qual a eficácia que podia ter este serviço oficial de fiscalizaçāo? Dados do próprio Ministerio do Trabalho (BMTIC, 1935, p.101-119) indicam que suas condições de operação eram difíceis. Durante o ano de 1934, menos de $10 \%$ dos estabelecimentos industriais, comerciais e bancários do Rio de Janeiro conseguiram ser visitados. Faltava pessoal, material adequado $e$, não menos, interpretação das inúmeras leis que, em certos casos, colidiam entre si. Finalmente, a animosidade dos empresários é registrada como um dos mais fortes obstáculos para a ação de inspecionar oficialmente, mesmo que esta inspeção não pudesse ser feita para todos os itens que compunham a condição e as relaçōes de trabalho. Isto explica também o elevado número de greves por empresa que cortam os anos iniciais da década de 30; delas, o operariado parece ter aprendido que a 
efetiva vigência das leis só existiria se os trabalhadores enfrentassem seus patrões, para tomar reais seus direitos mais essenciais. A questão da vigência real e cotidiana das leis colocava, portanto, o governo, os empresários e os trabalhadores em um enfrentamento constante, variado e desigual em torno da configuração do espaço público que se abria com a negociação da condição operária, mesmo a partir de uma regulamentação vinda de cima a respeito das relações entre trabalho e capital.

Parece, portanto, admissível suspeitar que não foi apenas no plano sindical que a Estado retirou ação e autonomia dos trabalhadores, mas também no plano do próprio processo cotidiano de trabalho, vivido como experiência de sociedade e passível de expressão coletiva e pública. Nele parece ter ocorrido o mesmo mecanismo de dominação que se expressa na Legislação Sindical: o Estado dá uma resposta àquilo que é exigido, encontrando assim o cerne das reivindicações operárias formuladas na luta cotidiana fabril e que haviam formado os trabalhadores como classe; regulamenta, assim, a luta, pondo limites na pretensāo dos patrōes em tudo decidir e enfatizando a vigência simbólica de direitos particulares; e, como já foi bastante notado, distribui ganhos e perdas para aumentar sua própria autonomia como poder. Por isso lhe é possível, através da linguagem simbólica da lei, simultaneamente, conhecer e desconhecer a linguagem operária que elaborava o temário de suas reivindicações; eliminar e exaltar a possibilidade de os trabalhadores cobrarem ativamente a vigência de suas conquistas; temer e ignorar a capacidade de os trabalhadores lidarem coletivamente com a disciplina imposta de cima para baixo. Foram estas as perdas reais que a era do Estado inaugurou como norma no próprio interior da fábrica e na sua expressão exterior como ação política. Em outros termos, os direitos do trabalho se internalizaram como regras legais no plano do próprio processo de trabalho, mas deslegalizaram a sua expressão como ação de luta política - e, portanto, legalizaram também a repressão.

\section{Os Direitos dos Trabalhadores: a experiência vivida}

Quando o golpe de Estado de novembro de 1937 aconteceu, ele apenas cristalizou a destruição daquilo que Getúlio Vargas chamou de "arenas de lutas estéreis" - isto é, os movimentos populares e partidários organizados - que estava sendo feita desde o final de 1935. A intensa repressão a sindicatos, jornais, intelectuais, militares, parlamentares e militantes dos movimentos que haviam crescido e se generalizado nesta época acabou com a emergente tentativa de uma política de mobilização social esboçada na primeira metade dos anos 30 , e que tinha a condição trabalhadora como seu centro. Sobretudo, matou a possibilidade de uma formação real de um espaço público diferenciado de informação, debate e elaboração nova das questōes sociais.

Nesta tragédia, o campo de luta entre empresários, trabalhadores e governo foi redefinido, e é esta redefinição que importa apreender. Pois nela está

Quando o golpe de Estado de novembro de 1937 aconteceu, ele apenas cristalizou a destruição daquilo que Getúlio Vargas chamou de "arenas de lutas estéreis"... inscrita a vivência das leis do trabalho no dia-a-dia da condição trabalhadora, nas inúmeras empresas (de todos os tamanhos) que se espalhavam e cresciam pelo país. Nela, portanto, está se processando uma experiência de proletarização que, embora desigual e heterogênea, não coincide com o fulgurante espetáculo do discurso redentor do Estado, especialmente no que se refere às condiçōes de trabalho e dos padrões de extração do sobretrabalho. Não se trata de 
contrapor um discurso falso a uma experiência verdadeira, mas sim de situar a questão que nos ocupa - a produção de uma figura pública e legítima de trabalhadores - para um lugar preciso: a luta (de classes) pelos direitos de representação autônoma e pela própria equivalência jurídica.

Embora a forma ditatorial de governo tenha sugerido para a história apenas os equívocos e o silêncio da luta e do protesto, estas nāo se congelaram, mesmo que sua forma tenha mudado pelas poucas chances de se manifestar abertamente. Houve, em primeiro lugar, a continuidade das resistências operárias nas fábricas contestando a exploração corrente e os abusos empresariais aos direitos fundamentais dos trabalhadores. Em segundo lugar, certos sindicatos tentaram aproveitar o próprio temário governamental para reivindicar a aplicaçāo real dos preceitos da CLT, mesmo com todas as limitaçöes impostas à sua organização. Em terceiro lugar, as promessas contidas nas florescentes políticas sociais do governo não impediram a corrosão dos níveis de vida urbana, e sequer a garantia de um salário mínimo legal pôde segurar o aumento das disparidades sociais. Isto fez emergir, por volta de 1944, um protesto urbano de consumidores impacientes que, ao mesmo tempo que os trabalhadores, opunham-se às restrições econômicas de sua sobrevivência ligadas aos privilégios obtidos pelos industriais, protegidos pelo governo autoritário. Nada disso ocorreu de modo sistemático e organizado; mais do que nunca, é neste período que as lutas sociais ocorrem de modo desigual e fragmentado, impedidas de se organizarem pela repressão e obscurecidas pelo espetáculo brilhante do Estado.

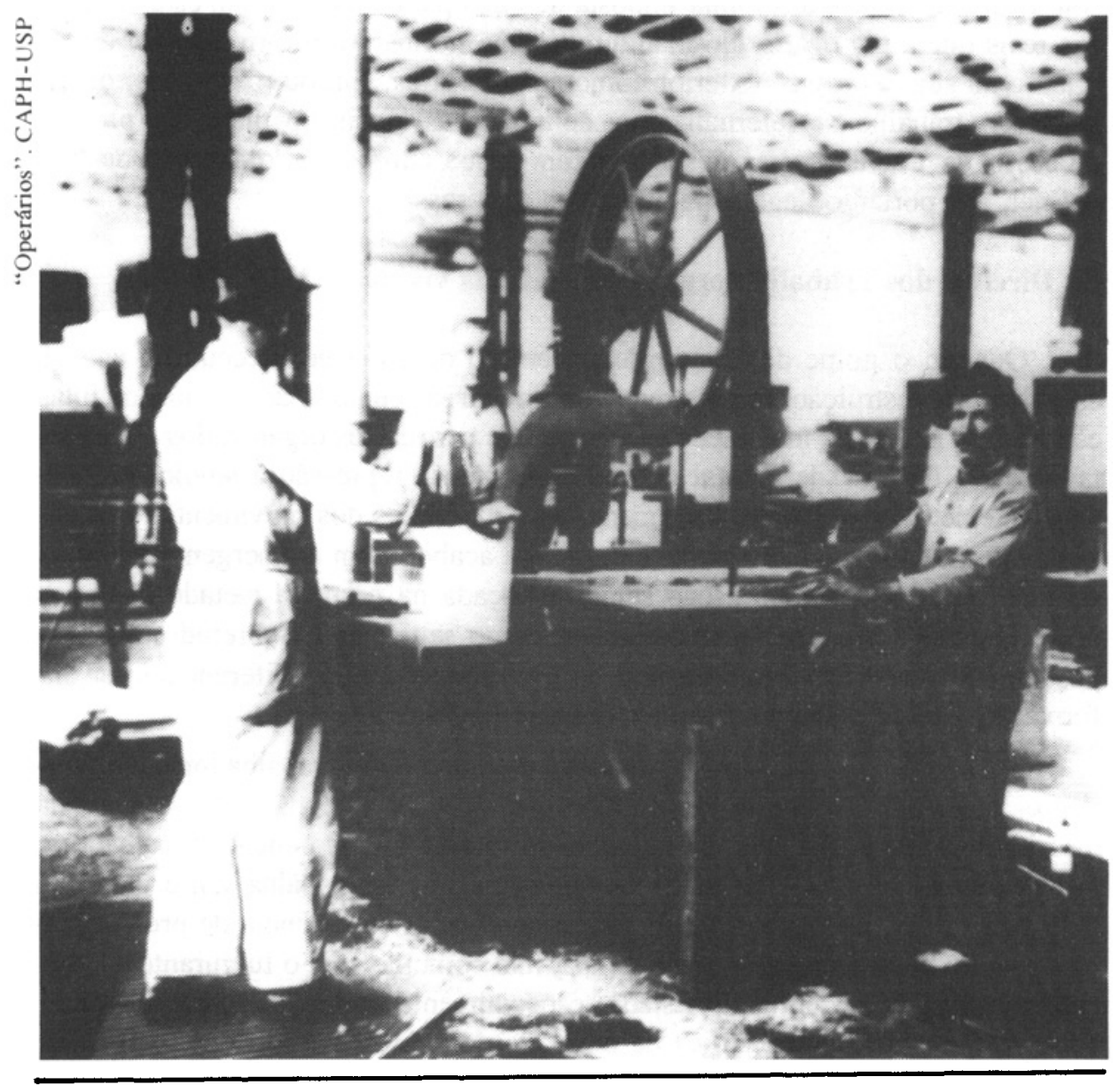


Mas a forte repressão à constituição e funcionamento dos grupos formais e informais de empresa fez com que outras formas de resistência e rebeldia ganhassem certa evidência. Sabe-se disso através dos próprios textos jurídicos divulgados pelo Ministério do Trabalho (ensaios doutrinários e respostas a consultas jurídicas), publicados entre 1936 e 1941 . Nestes textos, começa a aparecer, insistentemente, a ênfase em como lidar com "atos de indisciplina e insubordinaçāo", (mal) definidos na Lei n 62 do Código Civil de 1935. Para os operários industriais, tais atos eram descritos como "atos de violência, de desobediência reiterada ao regulamento, de insubordinação ao regimento interno e às instruçöes e ordens emanadas dos superiores hierárquicos" (Lei no 62, 1935; Decreto-Lei $\mathrm{n}-20.465,1933$ ). Isto era falta grave, e permitia aos empregadores despedir imediatamente o trabalhador acusado, sem aviso prévio nem indenização. Estas garantias caíam por terra se o empregador alegasse os "atos de insubordinação" e também "o desinteresse no desempenho da funções", a "incontinência de conduta, que tome o trabalhador incompatível com o serviço", além de agressividade física, embriaguez, prática de jogos de azar, negociação por conta própria e, finalmente, preguiça e má vontade (id. ibid.) ${ }^{13}$.

Seria espantoso imaginar que qualquer trabalhador fabril brasileiro das décadas de 30 e 40 - trabalhando duramente no interior de uma organização arbitrária do processo de trabalho e em péssimas condições salariais - não tivesse alguma reação que o incluísse em algum item desta lista de faltas. A lei que regulamentava a despedida e perda de emprego funcionava, portanto, mais como uma ameaça que repunha o puro mando patronal dentro das fábricas, visando manter sob seu controle a conduta (e a produtividade) dos seus trabalhadores. Deixando aos patrōes a especificação do que eram "justas causas" ou "faltas graves", a lei retirava dos trabalhadores a garantia que dizia conceder. Como parece ter sido regra das leis sociais trabalhistas brasileiras, ao conceder legalmente direitos fundamentais aos trabalhadores, o governo simultaneamente abre brechas para a manipulação empresarial destes direitos. E, para coroar, de fato, o cerceamento destes direitos, a ineficiência geral dos órgãos de julgamento que exigiam afastamento do trabalhador envolvido em um processo de reclamação enquanto este durasse, de modo que o trabalhador não trabalhava nem recebia salário - fazia com que este fizesse qualquer acordo com seu patrão (Apud BERNARDO, 1982, p.116).

Assim, até 1942, "suspensōes" de trabalhadores por motivos disciplinares

Como parece ter sido regra das leis sociais trabalhistas brasileiras, ao conceder legalmente direitos fundamentais aos trabalhadores, 0 governo simultaneamente abre brechas para a manipulaçâo empresarial destes direitos. aparecem nos julgados das Juntas de Conciliação e Julgamento, mostrando as tentativas patronais de não pagar as indenizações e dar avisos prévios. Houve alguns patrões que até inventaram a figura de "suspensão permanente", conseguindo irritar juízes que lhe esclarecem que isto quer dizer dispensa. Mas o que importa aqui é a crescente referência a julgados deste tipo, o que indica (para além da manipulação patronal) uma possivel alta frequiência de "atos de insubordinação" - ainda mais considerando que nem todos os casos chegavam à Justiça. Desse modo, minúcias do comportamento operário são descritas e julgadas, como, por exemplo, embriaguez esporádica ou habitual, reclamaçóes de trabalhadores sobre mudança de horário de trabalho, faltas e seus motivos, importância de antecedentes criminais, pequenos furtos (de pregos, de linhas, de

13 Sobre o assunto, cf. os pareceres juridicos, publicados na Revista do Trabalho de Adamastor Lima, "Despedida injusta", julho de 1936; Oliveira Vianna, "Parecer", março de 1937 e 1939; Ańbal Freire, "Parecer" setembro de 1939. 
metros de tecido), "abandono" de emprego por doença, agressões físicas, reclamaçōes operárias de mudança de horários, seçōes, funçōes e até do local da fábrica ${ }^{14}$. Tudo isso era objeto de discussōes entre patrōes e a justiça trabalhista, pois os diretamente interessados, não podendo dispor da pressão sindical (os casos de despedida estavam fora da alçada dos sindicatos), compareciam apenas com seu problema puramente individual diante da força política dos empresários. Na maioria dos casos, as Juntas decidiam pelas razōes patronais, nem que fosse pelo fato de que, até 1938, o "inquérito administrativo" para apurar falta grave do trabalhador era conduzido, por lei, apenas pelos patrōes.

Não parece haver dúvida do fortalecimento dos patrōes para burlar e limitar os direitos legais dos trabalhadores durante o período do Estado Novo. Em vários processos das Juntas de Conciliação e Julgamento (e mais tarde, da Justiça do Trabalho) aparecem todos os "pequenos" atos pelos quais os empresários, de modo mesquinho, garantiam para si o poder na fábrica por sobre a legislação do trabalho. Nâo afixavam o quadro de horário de trabalho, o que era obrigatório; recusavam-se a contar os dias de trabalho corretamente para o cálculo das férias; não davam repouso semanal na base de uma classificação profissional errônea de seus empregados; emitiam recibos de indenização parciais, aproveitando a pouca informação dos trabalhadores; não remuneravam corretamente as horas extras e o trabalho noturno - e havia empresas reincidentes que eram apenas advertidas pelo Ministério. O próprio "aviso prévio" de despedida era dado em prazos convenientes aos patrōes (mutáveis segundo as empresas) e não segundo os prazos previstos por lei (BMTIC, 1934, p. 205-08) ${ }^{15}$.

Não admira, portanto, que a recusa operária às disposições disciplinares das fábricas fosse recorrente entre os trabalhadores, mesmo que todos quisessem assegurar um emprego nos anos finais da década de 30 - quando a indústria ainda se considerava em crise (a "superprodução têxtil") e os empregos eram escassos. $\mathrm{Na}$ indústria têxtil, particularmente, aumentava o desemprego, generalizava-se a reduçäo salarial e ampliava-se a jornada de trabalho para os trabalhadores que quisessem ficar - medidas clássicas do empresariado brasileiro para enfrentar crises.

Neste contexto, os direitos valiam muito pouco e os patrões prosseguiam a expansão dos seus lucros e de suas fábricas de modo também clássico, não tomando medidas' nem diante da deterioração constante das condições de trabalho. Os jornais sindicais pediam mais higiene, ventilação e luz e denunciavam as apertadas instalaçōes dos banheiros usados como vestiários, sujando tanto a roupa de trabalho como a "roupa decente" de andar na cidade. O estado de ânimo "enervado, revoltado e torturado" dos motoristas de ônibus em 1941, devido a baixos salários e grandes jornadas, talvez pudesse ser estendido a todos os trabalhadores, submetidos por todos os lados a uma sucessão infindável de "pequenas" repressões do cotidiano de trabalho (O Trabalhador Têxtil, 1939; CARONE, 1976, p.123) ${ }^{16}$.

14 Sobre o assunto cf. $O$ observador económico e financeiro, ano I, (5): 107, junho de 1936. A revista Indústria Têxtil, ano X (109): 43-44, jan. 1941; e ano X (110): 70-71, fev. 1941.

15

16

Cr., tambêm, Indústria Têxtil, ns 109,110,119,156 (cobrindo os anos de 1941 a 1943).

A exploração intensa e uma sensaçāo de imutabilidade das relaçōes de trabalho nos anos iniciais da década de 40 são confirmadas pelas entrevistas feitas no programa Memória e História do Processo de Trabalho Fabril - Cidade de São Paulo do Departamento do Património Histórico da Secretaria de Cultura do Município, 1989. 
Até onde podiam, os trabalhadores não ficaram quietos. Mesmo nos setores onde o desemprego aumentava, onde a exploração crescia e as leis trabalhistas e sindicais só funcionavam para cercear o protesto operário, encontramse as resistências e reclamos pela manutenção e aplicação dos direitos. Documentos enviados pelos sindicatos ao Ministério do Trabalho mostram, por exemplo, que as fábricas continuavam a estender a jornada sem que o governo tomasse medidas, "enquanto os protestos sindicais só encontram indiferença" (CARONE, 1976, p.123), segundo os têxteis de São Paulo. Em 1940, o mesmo sindicato denunciava ao MT fábricas onde dois turnos eram feitos com uma turma de operários apenas; a tentativa dos patrões em alargar a noção de "aprendiz" para jovens de até 21 anos; descontos arbitrários de salários. E também denunciavam o medo dos trabalhadores em admitir ao fiscal do MT as denúncias feitas, pois poderiam ser despedidos (O Trabalhador Têxtil, 1940). Assim, parece claro que neste período os empresários puderam evidenciar seu sempre intacto projeto de tomar conta da fábrica como espaço seu, exclusivo, não obstante a legislação continuar a ser emitida. Calados os movimentos sociais e atrelados os sindicatos, os empresários puderam viver um momento âreo deste projeto.

O golpe mais baixo veio, no entanto, com a plena produção (sobretudo têxtil) trazida com a Segunda Guerra Mundial. Três decretos governamentais "restauraram" o dia de dez horas obrigatório (contra $20 \%$ de pagamento de horas extras), a produção ininterrupta e 0 acúmulo de turnos; aboliram as férias nas indústrias consideradas como de "segurança nacional"; e aboliram o direito de mudança de emprego nelas, sendo seus trabalhadores redefinidos como recrutas do trabalho e portanto como desertores se faltassem ou abandonassem o serviço. Além das fábricas de materiais de guerra, a indústria têxtil conseguiu definir-se como "indústria de guerra".

Apesar de toda a repressão existente, há sinais de que os trabalhadores tentaram novamente resistir à volta de uma exploração sem limites. Sabe-se disso através do próprio discurso patronal e, também, do governo. A partir de 1941, exatamente quando as exportações brasileiras começaram a crescer, as revistas patronais, as publicaçōes governamentais e as publicaçōes jurídicas especializadas começaram também a discutir como "incutir nos trabalhadores o interesse pela profissāo" (VIANNA, 1944a). Para ocupar o mercado aberto pela guerra, a indústria têxtil teria que produzir ao máximo - o que implicava, nas condiçōes vigentes de produção, ter o máximo de controle possível sobre a produtividade dos trabalhadores. Mais do que nunca, isto significava classicamente manter a boa disciplina dos trabalhadores, dado que nenhum outro recurso podia ser mobilizado para aumentar a produtividade - nem máquinas mais eficientes, nem modificação das relaçōes de trabalho. Aparentemente, a resistência dos trabalhadores a esta disciplina crescia na mesma medida destas exigências: do final do ano de 1942 até 1945, os textos patronais e governamentais

Assim, jâ em 1942, os juristas começam a definir o que são atos de sabotagem e julgar certas pendéncias trabalhistas sob esta definição. adquirem um tom de advertência e a palavra sabotagem torna-se freqüente.

Assim, já em 1942, os juristas brasileiros começam a definir o que são atos de sabotagem e julgar certas pendências trabalhistas sob esta definição. Sabotagem incluía aí "diminuir a quantidade da produção (vulgarmente "fazer 
cera' no trabalho); diminuir a qualidade da produção; danificar o maquinário, a matéria-prima, difamar o produtor ou a produção (boicotagem), praticar o obstrucionismo aplicando com absurda meticulosidade os regulamentos" (CAMPOS, 1942, p.433) ${ }^{17}$. Em 1943, líderes sindicais foram convocados para reforçar a "convocação militar" dos trabalhadores, além de ter saído um decreto que conferia aos sindicatos o direito de "combater o quintacolunismo nas fábricas e usinas (Decreto-Lei n- 4637, 1943). Assim, por exemplo, um membro da então se formando Confederação Nacional dos Trabalhadores na Indústria faz uma fala na Rádio Cruzeiro do Sul do Rio de Janeiro encorajando os trabalhadores a não só produzir muito, como também a "denunciar implacavelmente os derrotistas e sabotadores, qualquer que seja o matiz com que se apresentem". Nesta fala, derrotistas e sabotadores eram os que provocavam o enguiço das máquinas, eram indolentes ou tinham "má vontade" - o que quer dizer a recusa a limpar as máquinas de graça, a lentidăo em sua operação, a recusa em seguir o ritmo de trabalho exigido, a reclamação contra a qualidade da matéria-prima. Os trabalhadores que assim procediam eram agora considerados "suspeitos, individuos perigosos, quintacolunistas". A nova tarefa dos "soldados do trabalho" e dos "sindicatos quartéis" era, no campo de batalha das fábricas, "produzir e vigiar” (BMTIC, 1943).

Embora os trabalhadores estejam silenciosos, cercados como estavam por repressōes de todo tipo, parece claro que na prática sua resistência crescia, porque a fala patronal e governamental se dirige insistentemente para as questōes de disciplina interna das fábricas. No primeiro semestre de 1944, a revista Indústria Têxtil publicava notas e artigos sobre a "necessidade de soluçāo imediata para os problemas internos" das fábricas: "a mão-de-obra começa a faltar", diz um destes artigos "e a aplicação larga do regime de trabalho em tempo de guerra não vem sendo executada", continua. "Os operários afastam-se um ou dois dias por semana das fábricas para procurarem outro trabalho mais remunerador - que facilmente encontram, pois os salários em outras atividades são maiores, devido à falta de braços". Esta notícia é tanto mais significativa quanto se sabe que o decreto 4937, de 1942, havia proibido a mudança de emprego e punia fortemente as faltas dos trabalhadores. Os jornais de São Paulo e Rio, pela mesma época, insinuavam que a própria lei era culpada por tal situação, ao cercear os operários no interesse estrito dos industriais, e sugeriam que se deixassem operários e patrões "à vontade" para concluírem convençōes coletivas "em situação de mútuo interesse" (Indústria Têxtil, 1941).

Os empresários estavam longe de querer qualquer tipo de negociação. Sua percepçâo do problema operário centrava-se exclusivamente na questão da disciplina para o trabalho, ou seja, como forçar os trabalhadores à produtividade ideal. Esta miopia dos patrōes pode ser vista no debate travado através de suas publicaçōes, onde procuram modelos para domesticar os trabalhadores - modelos estes que estavam em vigência nos países atrasados ou totalitários da época: nesse caso, a sua tradicional profissão de fé liberal decididamente não servia. Assim, citam o caso japonês de regime de internato para moças operárias (e têm a ousadia de afirmar que se trata de obra de beneficência) ou suspiram com a evocação da operária russa Vinogradowna (versão feminina do staknanovismo). Sua auto-imagem chega às raias do ridículo quando publicam um
... o governo emitiu a Lei de Mobilização Industrial, feitá especialmente para a indústria têxtil. Nesta lei, muitos dos direitos dos trabalhadores foram suprimidos de vez. 
código de bom comportamento fabril, inventado pelo diretor do DNT - que é emblemático dos valores que os patróes tinham e da estrutura de gerência fabril que desejavam (além de mostrar o quanto os próprios burocratas do MT não assimilavam o que vem a ser direitos do trabalho): este código era fundamentalmente moral e seu regulamento parece ser o de um internato escolar (VIANNA, 1944b).

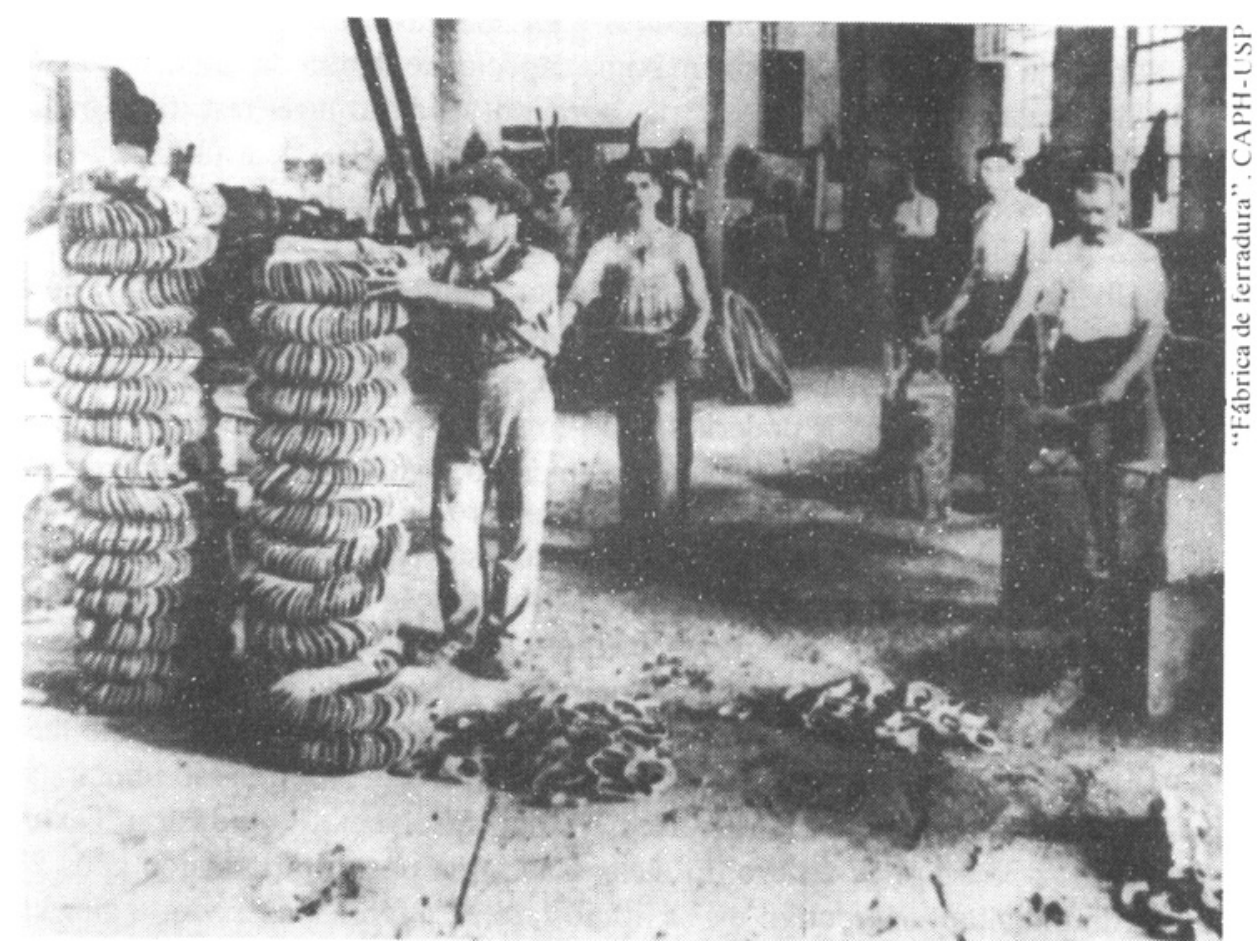

Em 1944, a luta contra a deserção e sabotagem parece ter chegado ao seu pico - embora nada disso se torne um assunto público, dada a imagem de harmonia e integração social que a ditadura getulista continuamente fabricava. Mas as advertências governamentais se tornam freqüentes neste ano de 1944. Como por exemplo no célebre programa governamental de rádio A Hora do Brasil, uma emissão obrigatória para todo o País irradiada no começo da noite. Nela, o Ministro do Trabalho, Marcondes Filho, alerta constantemente contra "aqueles operários que, após as leis do Presidente Vargas, ainda deixam cair o índice de produção". Analisando as causas deste comportamento dos trabalhadores fabris, o Ministro declarou que "não posso encontrar excusa no fato de se tratar de gente simples ou inadaptada ao ofício, porque ja produziram mais do que atualmente, ao tempo de menor salário..." (MARCONDES FILHO, 1944). Em outra palestra, o Ministro declarou que a queda da produtividade vinha basicamente por duas causas: falta ao serviço e decréscimo de eficiência. A falta ao serviço seria "uma triste demonstração de individualidade", querendo dizer que os operários se contentavam com baixos salários e com baixos nf́veis de vida; quanto à queda de eficiência, o Ministro atribuía à incompreensäo dos trabalhadores de seus direitos sociais. Mas não deixou também de se referir aos "elementos nocivos", cuja "preguiça física", "ignorância" e "má fé" impediam a "obediência aos sagrados deveres do patriotismo" (id. ibid., 1944).

No mesmo ano, consultas de sindicatos (têxteis, sobretudo) chegavam ao 
MT, pedindo para submeter suas pendências trabalhistas à Justiça do Trabalho e não às autoridades militares (as indústrias têxteis estavam definidas como indústrias de guerra. E o MT, implacavelmente, limitava-se a responder que "uma vez colocado o estabelecimento industrial sob a autoridade militar, cessa nele a obrigatoriedade da legislação do trabalho" (Indústria Têxtil, 1944, p. 3235; BMTIC, 1944).

Em junho de 1944, respondendo à pressão patronal que alegava estarem as fábricas já produzindo com sua máxima capacidade dentro da organização de trabalho prevalecente - o que exigiria, portanto, medidas mais restritivas ainda sobre os direitos dos trabalhadores - o governo emitiu a Lei de Mobilização Industrial, feita especialmente para a indústria têxtil. Nesta lei, muitos dos direitos dos trabalhadores foram suprimidos de vez. Tornou-se permitido o serviço de mulheres e crianças de mais de 16 anos em trabalho noturno; foi permitido 0 trabalho contínuo, isto é, aos domingos e feriados; reafirmou-se que nenhum trabalhador poderia mudar de emprego sem o consentimento do seu patrāo e nenhum outro empregador poderia admiti-lo sem a prova deste consentimento; mais de oito faltas formava abandono de emprego, punidas com penas de prisão que variavam de 15 dias a 6 meses. Em novembro de 1944, até os anúncios de propaganda industrial já haviam incorporado este padrāo de exploração sem maiores problemas, como por exemplo: "Prorrogação de horário de trabalho impōe a necessidade de iluminação melhor! Mude para as lâmpadas fluorescentes Sudlux e sua fábrica produzirá melhor..." Ou então: "Cardar, Fiar e Tecer 24 horas por dia! Esta é a situação, hoje, das fábricas de tecidos! Não lhes sobra tempo para paradas para reparos e mesmo certos consertos são impraticáveis por falta de peças! Lubrificantes Texaco resolvem..." (Indústria Têxtil, 1944, p. 32-35). Em dezembro do mesmo ano, um operário desmaiou após 23 horas de trabalho consecutivo na Lanifício Jafet, e a fábrica despediu-o alegando “desídia" (preguiça) (id. ibid., 1945, 170) ${ }^{18}$.

Assim, a condição cotidiana de trabalho (sobretudo fabril) foi reduzida a uma condição de impotência e solidão. É por isso que faz sentido as resistências que, nesse seu isolamento e individualizaçāo forçadas, cada trabalhador fabril esboçou dentro das fábricas - e, ao que tudo indica, com eficácia, se consideradas em seu conjunto. Afinal, o que os empresários haviam conseguido, nestes anos iniciais da década de 40 , era reduzir a condição dos trabalhadores ao mais puro modelo privatista e escravocrata da passagem do século com a diferença que podiam utilizar-se de um já sofisticado aparato de Estado interventor das questões sociais pela via legal - o que piorava totalmente as chances de uma possível reação dos trabalhadores. No plano ideológico, utilizavam também o discurso do patriotismo e da guerra para tornar ilegal qualquer situação de afastamento do trabalho. Deste modo, a superexploração do trabalho voltou a ser o padrāo aberto que comandava a acumulaçāo do capital industrial, aceito pela sociedade e justificado pela lei.

\section{Consideraçōes Finais}

Explica-se assim por que, quando a ditadura Vargas caiu, a fábrica e seus temas tenham voltado a dar energia de resistência e luta autônoma ao movimento operário, postas nas greves turbulentas de 1946 e 1947. A prática de
... o que os

empresários haviam conseguido, (...), era reduzir a condição dos trabalhadores ao mais puro modelo privatista e escravocrata da passagem do seculo, com a diferença que podiam utilizar-se de um já sofisticado aparato de Estado interventor das questões sociais pela via legal. 
... o surgimento do cidadão capaz de formular seus direitos em práticas coletivas diferenciadas e confrontá-las entre si na construçăo de uma institucionalidade polftica legftima deve ser feito as custas de se abrir mão da idéia e do fascínio de um poder redentor. protesto coletivo dos trabalhadores mostra que sua expressão pública se exercia imediatamente nos horizontes dados por uma vida pauperizada e arrochada. Isto parecia excluir a dimensảo da política instituída (na forma como ela se dava) e, com isso, a reafirmação de que a crença na lei - e nos direitos que ela enunciava - eram exteriores ao espaço público de participação, à ação parlamentar e à organização partidária exercida nos anos da redemocratização. No entanto, este realismo popular não negava as marcas da justiça que eram prometidas pela legislação trabalhista; especialmente foram reconhecidos (e o são até hoje) os direitos previdenciários, o salário mínimo e os serviços assistênciais dos sindicatos. Mas a crença e o conhecimento dos direitos dos trabalhadores no processo de trabalho e a exasperação ao vê-los sem reconhecimento prático efetivo mantinham - e mantêm - uma relação direta com a forma explosiva com que os trabalhadores se fizeram ouvidos.

Mais uma vez, o foco de onde procediam as exasperaçōes com o Estado estava no nāo cumprimento das leis trabalhistas pelos empresários. Assim, o reconhecimento institucional dos direitos do trabalho, operado pelas leis, continuava a limitar e a desorganizar a experiência coletiva dos trabalhadores como ação: de uma parte, ela não chegava a se impor totalmente como concepção plenamente aceita de tutela; de outra parte, as resistências e os movimentos não tinham força para substituir o funcionamento da ordem legal única, imposta pelo Estado. A luta entre a justiça formulada pelos trabalhadores e a justiça proferida pela lei ${ }^{19}$ e também as suas estranhas formas de conciliação parecem balizar, há muito, as experiências fabris dos trabalhadores na constituiçāo e afirmação de si mesmos como presença e representação pública de classe.

Desse modo, a natureza ambígua dos direitos promovidos pelo Estado seu sucesso em promover identificações e seu relativo fracasso em produzir cidadāos a partir da idéia de justiça social - mostra uma experiência política de integração social cujo espaço é feito de práticas múltiplas, que continuam vivas apesar de o espetáculo estatal ter aparecido como ato único. A voz e a pessoa. que comandava este espetáculo não existia unicamente em seu texto e em sua figura; por isso, seu sucesso não pode ser explicado apenas nele (e em seu aparato de intervenção social), mas também nos homens e mulheres a quem se destinava. Por maior que tenha sidu o efeito de legitimidade deste discurso estatal protetor, seus destinatários não eram pessoas sem história, sem trajetos, sem biografia, sem interioridade, sem experiências de sociedade e de cultura. Por isso este discurso estatal é o lugar onde a multiplicidade de significados se reúne e se concretiza no encontro de vários sentidos, de várias tradiçōes, de várias contestaçōes. Sem isso, nāo é possível perceber no que a experiência social e sua expressão coletiva se afastam desta "cidadania regulada"20; em que lugar a fala do poder ignora, sufoca e destrói a sua própria idéia de constituir cidadãos e de mudar o horizonte desintegrado de uma nação. Para contar uma história onde a questão da legitimidade possa ser devolvida ao seu espaço democrático, é preciso subverter o mito de que o surgimento do cidadão capaz de formular seus direitos em práticas coletivas diferenciadas e confrontá-las entre si na construção de uma institucionalidade política legítima deve ser feito às custas de se abrir mão da idéia e do fascínio de um poder redentor.

\footnotetext{
19 Sobre a pluralidade normativa jurídica, em outra situação, cf. Boaventura de Sousa Santos, "Notas sobre a história jurídico-social de Pasárgada" em José Geraldo Sousa Jr. O direito achado na rua. Brasflia, UnB, 1987.

20

A noção de "cidadania regulada" é de Wanderley Guilherme dos Santos, Cidadania e Justiça. Ed. Campus, 1979.
} 
Referencias Bibliograficas

ADORNO, S. 1981. O liberalismo na formação da ordem social competitiva. São Paulo, (mimeografado).

ARENDT, H. 1979. As origens do totalitarismo. Rio de Janeiro. Documentário.

BEIGUELMAN, P. 1977. Os companheiros de São Paulo.São Paulo, Ed. Símbolo.

BERNARDO, A. C. 1982. Tutela e autonomia sindical: Brasil, 1930-1945. Sáo Paulo, T. A. Queiroz.

BOLETIM DO MINISTÉRIO DO TRABALHO, INDÚSTRIA E COMÉRCIO. Rio de Janeiro, n.3, nov. 1934.

-. Rio de Janeiro, n.7, mar. 1935.

. Rio de Janeiro, mar. 1943.

Rio de Janeiro, mar. 1944

BRASIL. Lei n 62, de 5 de junho de 1935.

. Decreto-Lei no 4.637 de 1943.

. Decreto-Lei no 20.465, de 1933.

CAMPOS, N. P. 1942. Antagonismos de interesses. In: Seminários de Legislação Social (1941-1942). São Paulo, Fac. de Direito/USP.

CARONE, E. 1976. O Estado Nevo. São Paulo. DIFEL.

CASTRO GOMES, A. 1979. Burguesia e trabalho. Rio de Janeiro, Ed. Campus.

CHAUf, M. 1986. Conformismo e resistência.São Paulo, Brasiliense.

FUNDAÇĀO DAS INDÚSTRIAS DO ESTADO DE SĀO PAULO. Circulares de 1931.

Circulares de 1934.

HALL, M. s/d. On widening the scope of Latin American working-class history: some general considerations and a brazilian case study. (mmeografado).

INDÚSTRIA TÊXTIL. São Paulo, n.151, jul. 1941.

—. São Paulo, n.148, mar. 1944.

São Paulo, n.155, nov. 1944.

. Săo Paulo, n.170, 1945.

LEFORT, C. 1986. Essais sur le politique.Paris, Editions du Seuil.

LEME, M. S. 1978. A ideologia dos industriais brasileiros.

MARCONDES FILHO, A. 1944. Cumprir as obrigaçōes para apressar o término da luta. Série de palestras radiofónicas, DIP, abril e maio.

MUNAKATA, K. 1981. A legislação trabalhista no Brasil. São Paulo, Brasiliense.

O TRABALHADOR TÊXTIL. São Paulo, nov./dez. 1939.

. São Paulo, n.21, ago. 1940.

PIMENTA, J. 1949. Retalhos do passado. Rio de Janeiro, Ed. Coelho Branco.

PINHEIRO, P. S. e HALL, M. 1981. A classe operária no Brasil, 1889-1930. Sào Paulo, Brasiliense, 2v.

SÁDER, E. 1988. Quando novos personagens entram em cena.São Paulo, Paz e Terra.

SIMĀO, A. 1966. Sindicato e Estado.Sāo Paulo, Dominus Editora.

VARGAS, G. D. 1938. A nova polttica do Brasil. São Paulo, Livr. Jose Olympio. V.I.

VIANNA, O. 1934. Fiscalização das leis sociais. BMTIC, Rio de Janeiro (4): 129-131.

VIANNA, S. 1944a. Problemas da māo-de-obra no Brasil. MTIC-DNT (mimeografado). 1944b. Todo empregado deve saber.O Jornal, abril.

Maria Celia Paoli é professora do Departamento de Sociologia da FFLCH/USP e participante do Ciclo de Seminários "Cem anos de República: continuidade e mudança", 1989, do IEA. 